RENATO PERICIN RODRIGUES DA SILVA

\title{
COOPERAÇÃO INTERNACIONAL NO COMBATE À PIRATARIA NA COSTA DA SOMÁLIA
}

Trabalho de Conclusão de Curso de Relações Internacionais para a Universidade de Brasília, apresentado como requisito à obtenção do título de Especialista em Relações Internacionais. 
RENATO PERICIN RODRIGUES DA SILVA

\section{COOPERAÇÃO INTERNACIONAL NO COMBATE À PIRATARIA NA COSTA DA SOMÁLIA}

Trabalho de Conclusão de Curso de Relações Internacionais para a Universidade de Brasília, apresentado como requisito à obtenção do título de Especialista em Relações Internacionais.

Orientadora:

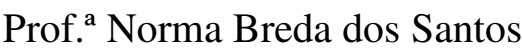

Brasília

2010 


\section{RESUMO}

Este estudo analisa a cooperação na segurança internacional no combate à pirataria marítima moderna na costa da Somália, mostrando como a pirataria se desenvolveu ao longo do tempo e, apesar dos ataques piratas serem semelhantes aos que eram feitos no século XVIII, eles têm formas e causas diferentes.

Para atingir seu objetivo, este estudo apresenta o impacto da pirataria marítima no comércio marítimo mundial e algumas questões problemáticas sobre como lidar com a dificuldade na definição do crime de pirataria no direito internacional. Em segundo lugar, apresenta os aspectos entrelaçados da globalização e da pirataria marítima e, finalmente, discute os recentes episódios de pirataria marítima na Somália com ênfase na cooperação entre os países envolvidos no evento.

O trabalho conclui que, apesar das diversas ações internacionais, sejam isoladas ou em conjunto, permanece o combate ao efeito e não à causa do problema. Esse combate à pirataria marítima moderna assume uma forma semelhante ao que era feito no século XVIII, isto é, o uso exclusivo da força contra os piratas. 


\begin{abstract}
This study analyzes the international security cooperation against modern maritime piracy in Somali coast, showing how the piracy has evolved throughout time and despite being similar to those performed in the eighteenth century have different causes and forms.

To achieve the goal, this study presents the maritime piracy impact on global maritime trade and some problematic issues on how to deal with piracy difficulty in defining the crime of piracy in international law. Secondly, presents the intertwined aspects of globalization and maritime piracy and, finally, discusses the recent episodes of maritime piracy in Somalia with an emphasis on cooperation between the countries involved in the event.

The paper concludes that, despite various international actions, whether alone or jointly, fighting remains to the effect and not to the cause of the problem. The fight against maritime piracy modern assumes a similar form to what was done since the eighteenth century, that is, the exclusive use of force against the pirates.
\end{abstract}


1 INTRODUÇÃ

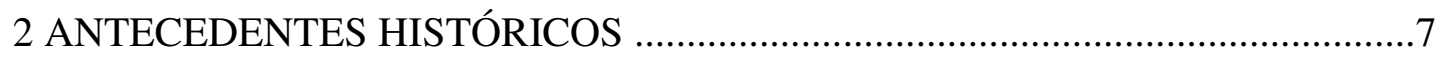

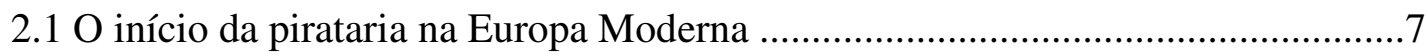

2.2 Aspectos históricos da Somália - Estado Falido ................................................

2.3 O surgimento da pirataria na Somália ...........................................................12

2.4 Perfil dos piratas modernos da Somália ...........................................................13

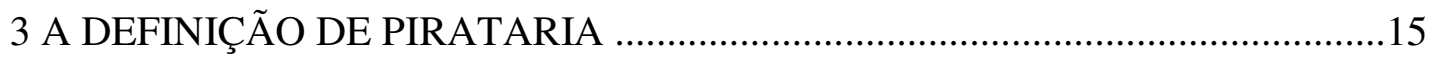

3.1 A definição da Convenção da Jamaica …….....................................................15

3.2 A definição da Organização Marítima Internacional ...........................................16

3.3 A definição da Convenção para a Repressão de Atos Ilícitos Contra a Segurança da Navegação Marítima ...................................................................................... 17

3.4 A polêmica sobre a definição de pirataria marítima ...........................................18

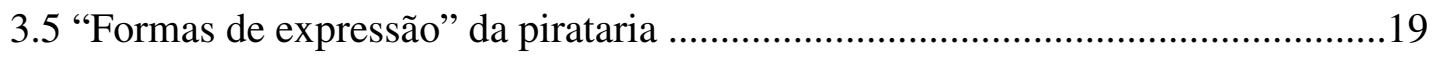

4 GLOBALIZAÇÃO E A PIRATARIA …............................................................22

4.1 A importância estratégica do Golfo de Aden ....................................................22

$4.2 \mathrm{O}$ impacto da pirataria no comércio marítimo internacional ...............................22

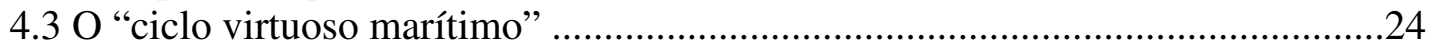

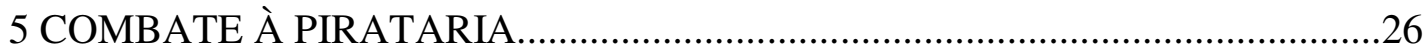

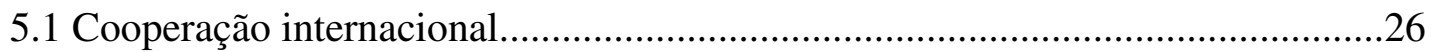

5.2 Operação ATALANTA - União Européia.......................................................29

5.3 Força Tarefa Combinada 151 - EUA e outros.....................................................30

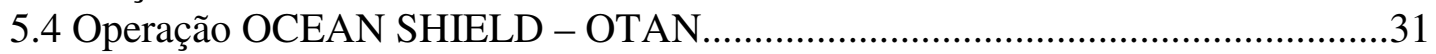

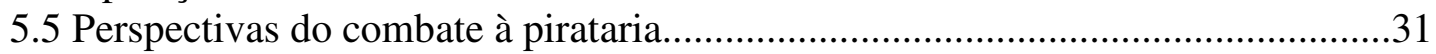

6 PIRATARIA E O DIREITO INTERNACIONAL, MARÍTIMO E DIREITOS

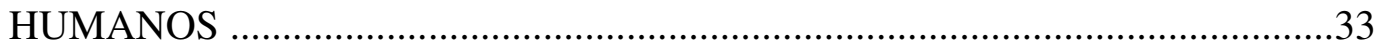

7 CONCLUSÃO

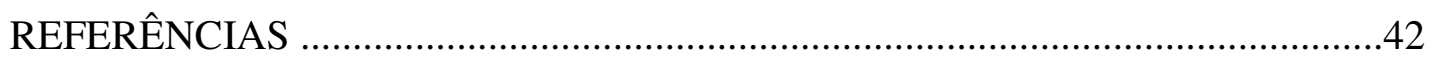




\section{INTRODUÇÃO}

A pirataria ${ }^{1}$ tem sido envolvida em uma atmosfera de mito e glamour, em parte por causa dos filmes de Hollywood, onde a indústria do entretenimento mostra a pirataria de forma um pouco romantizada. Ao assistir as aventuras do capitão Jack Sparrow $^{2}$ ou Long John Silver's ${ }^{3}$, a pirataria é geralmente associada a veleiros e histórias de aventura. No entanto observa-se que a realidade da pirataria marítima moderna é bem diferente da fantasia que permeia o pensamento comum.

Nascido sob a égide do Estado, a pirataria evoluiu para fins privados, e hoje em dia, segundo Plant (1990), está ligado ao terrorismo marítimo. Desde a década de 1980 até o fim do período desse estudo, o número de ataques de piratas tem crescido e atraído a atenção da mídia e dos governos dos países. A pirataria é uma atividade que evoluiu no seu padrão geográfico, objetivos e motivações.

O objeto desse estudo é a pirataria marítima praticada no Golfo de Aden, onde cerca de $70 \%$ da pirataria marítima do mundo se concentra. Cerca de $12 \%$ do comércio marítimo internacional e $8 \%$ do transporte de petróleo e derivados transportados pelo mar também utilizam a rota das águas do Chifre da África. A ameaça ao comércio marítimo internacional atingiu nível tal que motivou diversas ações multilaterais, sob o aval da ONU, para combate a essa ameaça que tem crescido de forma alarmante nos últimos vinte anos no Oceano Índico. O número de ataques piratas realizados no primeiro trimestre de 2009 superou o total dos realizados em todo o ano de 2008.

Existem diversos aspectos que devem ser considerados quando se tenta definir pirataria. Essa questão tem gerado diversas controvérsias entre o Direito Internacional e Marítimo. A definição é complexa e não existe consenso internacional sobre o tema. Essa indefinição jurídica não fica restrita aos tribunais, tendo em vista que serve de base para os Estados atingidos pelo problema na definição de políticas de combate à pirataria.

A globalização tem dentre suas principais características a intensa troca

1 Para os fins desse estudo, o termo pirataria sempre estará se referindo à pirataria marítima moderna. 2 Capitão Jack Sparrow é um pirata fictício e personagem principal da trilogia de hollywood "Piratas do Caribe".

3 Long John Silver era um dos principais piratas do livro Ilha do Tesouro, do escocês Louis Stevenson. 
de produtos de diferentes mercados. Essas trocas ocupam um volume muito expressivo e não param de crescer, sendo que a maioria (cerca de 95\%) é feita por transporte marítimo. Nesse sentido a pirataria marítima prejudica e tem uma ameaça potencial ao comércio internacional.

Este estudo analisa a efetividade da cooperação na segurança internacional no combate à pirataria marítima moderna na costa da Somália, mostrando como a pirataria se desenvolveu ao longo do tempo e, apesar dos ataques piratas serem semelhantes aos que eram feitos no século XVIII, ela tem diferentes formas e causas.

Para atingir o objetivo, este estudo apresenta o impacto da pirataria marítima no comércio marítimo mundial e algumas questões problemáticas sobre como lidar com a dificuldade na definição do crime de pirataria no direito internacional. Em segundo lugar, apresenta os aspectos entrelaçados da globalização e da pirataria marítima. E, finalmente, discute os recentes episódios de pirataria marítima na Somália com ênfase na cooperação entre os países envolvidos no evento.

O trabalho conclui que, apesar das diversas ações internacionais, sejam isoladas ou em conjunto, a pirataria tem sido combatida de forma semelhante ao que está sendo feito desde o século XVIII, isto é, mediante o uso exclusivo da força contra os piratas. Nesse sentido, mostrando que permanece o combate ao efeito e à causa do problema. 


\section{ANTECEDENTES HISTÓRICOS}

A pirataria sempre esteve presente no sistema internacional ${ }^{4}$ e ela é praticada em várias partes do mundo. Para o encadeamento lógico desse estudo, parte-se do princípio que a pirataria é o crime caracterizado por ataques a navios para fins privados, a fim de capturar a carga, o navio ou de ambos. Esta definição preliminar nos permite estabelecer um ponto a partir do qual se pode explorar a definição mais completa.

\subsection{O início da pirataria na Europa Moderna}

Segundo Chenoweth (1999), o início da pirataria no Europa moderna ocorreu com a instituição das cartas de corso. O primeiro desses documentos foi emitido em 1354, durante o reinado de Eduardo III da Inglaterra (1327-1377). Segundo Sidak (2005), as cartas eram documentos nos quais o monarca autorizava indivíduos (piratas) a usar a força para atacar e saquear Estados inimigos. As cartas continham um texto descrevendo a área, período e do Estado contra o qual o corsário estava autorizado a usar a força. O corsário poderia se envolver em atos hostis em nome do monarca em troca de parte do valor da carga (prêmio). O prêmio capturado seria adjudicado ao corsário depois de pagar os impostos reais. A existência destes documentos foi possível em parte devido à inexistência de uma marinha organizada e a falta de um controle que alinhasse os interesses privados e de governo. Assim, corsários tinham o direito de fazer a guerra através da emissão de cartas de corso. Se um corsário excedesse os poderes conferidos no documento, ele poderia ser considerado um pirata, embora essa distinção não fosse clara.

Os abusos cometidos pelos corsários no reinado de Henrique IV (13991413) colocaram o monarca em uma posição difícil de controlá-los, por que:

"Apesar de alguns crimes em alto-mar terem como único objetivo saquear, parte da pirataria foi a serviço dos interesses do reino, que veladamente autorizou não só a navegação de corsários não licenciados no Canal da Mancha, mas também serviu Henry de alguma forma legítima. O rei enfrentava a questão polêmica da punição dos “infratores”, negando-se muitas vezes a fazer a restituição,

\footnotetext{
${ }^{4}$ Nesse estudo, o sistema internacional é entendido como definido por Hedley Bull: "quando dois ou mais Estados têm contato suficiente com os impactos recíprocos de suas decisões, então fazem parte de um grupo". BULL, Hedley. A sociedade anárquica. Tradução Sérgio Bath. São Paulo: Imprensa
} 
sabendo que seus navios e os homens eram vitais para a defesa do país em tempos difíceis, especialmente quando um confronto aberto com os franceses poderia ocorrer a qualquer momento." (PISTONO, 1975, p.322)

Como o Estado era incapaz de oferecer segurança aos transportes marítimos, uma rede foi criada com a pirataria em seu centro, incluindo portos protegidos, comerciantes, especuladores, além do suborno aos funcionários da Coroa. Segundo Mathew (1924), a mercadoria roubada fluía para cidades do interior do país, por um grupo de pessoas que ganhavam uma percentagem do valor a ser intermediado por fornecer segurança. Havia refúgios em Dorset, na Cornualha, Irlanda e País de Gales que nunca foram utilizados por comerciantes legalizados. Os piratas recebiam um quinto do valor e o restante ficava com o comerciante em locais de maior risco. A ausência de guerra, especialmente na costa da Irlanda, fez a atividade bastante segura. Mesmo autoridades, como o Vice-Almirante Bristol, estavam envolvidos nas transações.

Para exemplificar, os Killigrews, uma das famílias mais importantes da Cornualha, foram responsáveis pelo controle de todo o fluxo de mercadoria saqueada na região. Em 1597, um navio pirata entrou no porto de Falmouth com sua carga e o capitão Killigrew embarcou. Na inspeção, Killigrew acertou com o capitão Jonas (o comandante pirata) que, "cobraria £ 100 para levá-los em segurança até o alto-mar".

As cartas de corso foram abolidas em 1856, pela Declaração de Paris, parte do Tratado de mesmo nome que pôs fim à Guerra da Crimeia.

Segundo BOOT (2009), estes casos mostram que a consecução de crimes no mar, com uma estrutura definida em terra não é uma coisa nova e nem é uma exclusividade de Estados Bárbaros. O fato é que a história é um produto das circunstâncias e qualquer tentativa de tirar lições e projeções de futuro a partir dela é enganosa e ingênua.

\subsection{Aspectos históricos da Somália - Estado Falido}

A Somália está localizada numa região conhecida como "Chifre da África", ou para os portugueses, "Corno de África". O nome pode ter sido originado pela forma pontiaguda daquela parte do Continente. A costa da Somália, com 3.000

Oficial do Estado de São Paulo, 2002, p. 15. 
quilômetros, é a mais extensa da África e faz parte de uma das mais importantes rotas marítimas do mundo. Isso ocorre porque a costa norte da Somália é banhada pelo Golfo de Aden, que é conhecido como rota marítima vital para o transporte de petróleo.

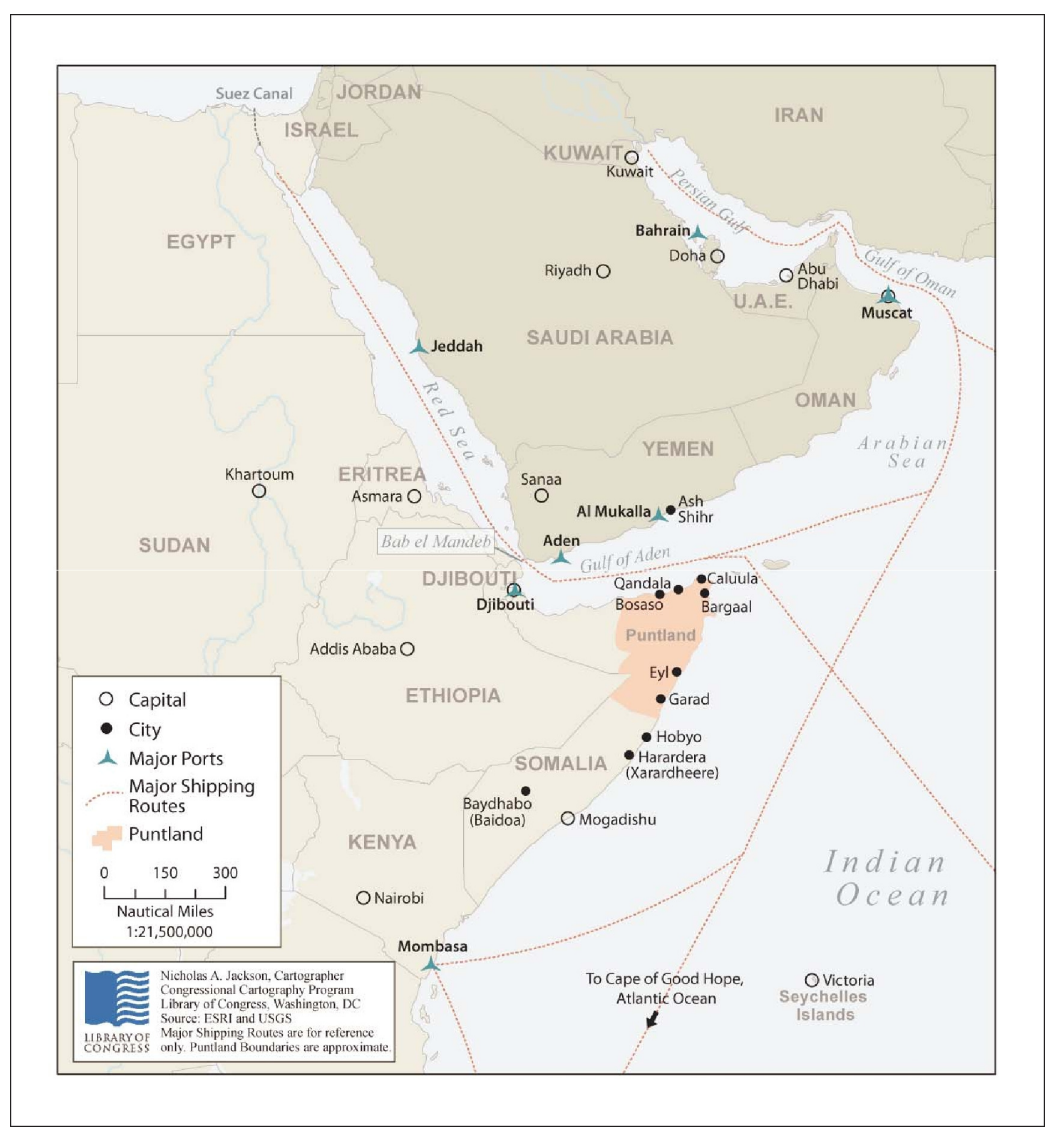

Figura 1 - O Chifre da África, águas adjacentes e pontos de interesse. Fonte: Serviço de Pesquisa do Congresso dos EUA, 2009.

Como afirma o cientista político Francis Fukuyama, Estados falidos representam ameaça em potencial para a comunidade internacional. A existência de Estados que não conseguem se impor de forma adequada perante seu território desencadeia problemas não apenas para o ambiente doméstico em questão, mas também em nível internacional.

Segundo o mesmo autor, a Somália constitui típico exemplo de Estado falido. Desde 1991, o país não possui um governo que, de fato, exerça controle sobre a integralidade de seu território. Dessa forma, inúmeros problemas surgiram no território somali, dentre os quais possui destaque a pirataria. A Somália não provê para seu povo serviços públicos sociais nem securitários, acabando por impor à 
população uma situação em que esta se vê desamparada e obrigada a, por si só, partir em busca de seu bem-estar. O povo somali não possui saúde, educação e moradia satisfatórias, o que o leva a empreender tentativas desesperadas, como as atividades piratas, para a obtenção de recursos financeiros que satisfaçam tais necessidades.

Desde a queda do governo do General Muhammad Siad Barre, em 1991, a Somália não possui um Governo Central. O país inclui a Somalilândia, localizada a noroeste e Puntland, no nordeste, onde, em razão do caos reinante, tiveram a oportunidade de realizar um movimento separatista e hoje possuem administração própria, sendo consideradas Repúblicas de Independência não-reconhecidas.

No Centro e Sul, chefes militares assumiram e impuseram suas autoridades. Assim, as Instituições Estatais destinadas a assegurar a aplicação da lei e da ordem desapareceram. Para proteger os seus interesses e dar segurança às suas respectivas circunscrições, esses grupos criaram milícias particulares.

O colapso do Governo Central na Somália levou o país a tornar-se progressivamente, não só um local de refúgio para alguns suspeitos de estarem ligadas a organizações terroristas, como também um local utilizado por pessoas e organizações privadas para transações ilegais. O novo Governo de Transição possui apenas controle limitado sobre o país. Fora da área estratégica da capital Mogadíscio, o Centro e Sul da Somália ora estão sob controle de elementos antigoverno, ora sob forças governamentais.

Nesse contexto, há duas décadas, coexistem os empresários oportunistas de dentro e fora da Somália, as redes de organizações criminosas e os cidadãos desempregados envolvidos em atividades ilegais, aí incluídas a pesca ilegal, o contrabando de migrantes e a internação ou despejo de resíduos tóxicos ao longo da costa da Somália. Esse ambiente fez com que os interesses econômicos tivessem maior peso do que a existência de uma estabilidade governamental e de uma regra de direito para o estabelecimento da ordem e da segurança no país, levando-os a ficarem nas mãos de algumas pessoas e organizações particulares.

A concorrência dos interesses econômicos entre os diversos beneficiários do Estado e o desequilíbrio nas responsabilidades das instituições, contribuíram para a falência do poder central e no aumento da pobreza e das taxas de desempregos da população local, em especial dos jovens, conduzindo-os a aderir às milícias ou a agirem como bandidos, participando de atos criminosos como bloqueios, seqüestro 
de estrangeiros, contrabando de imigrantes e pirataria.

O setor pesqueiro não é muito desenvolvido na Somália, sendo destinado majoritariamente ao consumo local, e não para exportações. Esta atividade pode ser lucrativa em um contexto de estabilidade, mas no cenário atual é problemática. $\mathrm{O}$ grande problema adveio do fato de que os navios pesqueiros agiam propositalmente em detrimento dos pescadores locais: destruíam os equipamentos de barcos menores, cortavam suas redes de pesca e até mesmo atacavam navios somalis.

Segundo Zago (2008), a incapacidade de uma autoridade legítima controlar a costa é responsável pelos efeitos observados na atualidade, sendo um deles a pesca predatória. Ela é feita por navios pesqueiros de diversos países, que utilizam as águas somalis, extremamente ricas, para a pesca sem respeitar as licenças pesqueiras, visto que, com a presente situação de caos, não há contato legítimo com a Somália. O TFG emite licenças, assim como Puntland e Somalilândia, mas como é possível utilizar as águas sem licenças devido à falta de fiscalização há muitas embarcações que não as adquirem e agem pescando clandestinamente. Diversos navios possuem licenças emitidas por warlords, que assim financiam suas atividades e permitem a ação estrangeira. Além da pesca, contando com a ausência de fiscalização, navios estrangeiros também se aproveitam das águas para esvaziar e limpar de seus tanques resíduos químicos, o que provoca a contaminação das águas e consequientemente de recursos essenciais para as populações litorâneas.

A ausência de ordem nas terras somalis propiciou um ambiente que permite ausência de ordem no mar. Sem uma autoridade oficial, a pesca passou a ser feita sem licenças, e se tornou uma atividade perigosa - não por sua própria natureza, mas pela presença de outros pescadores na região. A pesca estrangeira é realmente prejudicial para os pescadores, pois os navios em questão navegam por cima das suas redes pesqueiras e lançam dejetos sobre suas embarcações, além de utilizar métodos de pesca proibidos internacionalmente sem fiscalização ou controle, reduzindo significativamente o sucesso dos pescadores somalis. A pesca internacional é feita sem a preocupação com os padrões da Organização Internacional do Trabalho (OIT) e da Organização Marítima Internacional (OMI). Assim, muitos dos barcos não oferecem cuidados médicos, roupas ou horas de descanso apropriados para a tripulação. É uma atividade muito lucrativa: antes da guerra civil somali em 1991 produzia cerca de 20 mil toneladas de pesca por ano, quantia que aumentou depois 
dos conflitos, devido à falta de fiscalização.

\subsection{O surgimento da pirataria na Somália}

A Somália encontra-se com suas instituições de segurança pública sensivelmente deterioradas. Não há policiamento interno ou defesa apropriada dos bens nacionais. Por isso, a população encontra-se livre tanto para cometer crimes e permanecer impunes quanto para formar suas próprias milícias para "proteger", autonomamente, os bens do país.

Esssa justificativa é utilizada pelos piratas somalis que cometem seus crimes na costa e alegam que fazem, em realidade, o patrulhamento das águas da Somália.

Percebe-se, no entanto, que a pirataria somali é resultado de um processo longo e complexo, durante o qual o Estado deteriorou-se e, por conseguinte, seu povo viu-se livre para cometer crimes dessa natureza.

Os navios mercantes aproveitam-se da situação de ausência da presença governamental para efetuar a limpeza dos seus tanques, lançando lixos tóxicos ou radioativos nas águas da Somália, destruindo pela poluição o leito marinho e o rico e habitat natural das espécies. Tudo isso somado, induziu naturalmente aos somalis capturarem alguns barcos de pescas estrangeiros efetuando pesca ilegal nas águas jurisdicionais, tomar suas cargas e/ou cobrar algum tipo de multa/taxa, como uma maneira de compensar suas perdas e de punir e proteger o já pobre recursos naturais de suas águas. Foi, portanto, dessa forma que surgiram os primeiros piratas da Somália. ${ }^{5}$

A pirataria do início dos anos 1990 era dirigida a navios pesqueiros e visava, primordialmente, restabelecer a pesca regional. No entanto, o potencial de se obter lucro fazendo-se uso de sequestros e exigindo-se uma contrapartida financeira para a libertação de navios e tripulações atraiu a atenção de outras parcelas da população somali. Em especial senhores da guerra e homens de negócio perceberam que, se explorado em maior escala, o ramo da pirataria poderia conferir vultosos dividendos. Assim, o número de seqüestros cresceu e eles deixaram de ser estritamente ligados aos pescadores.

A pirataria tornou-se a principal atividade econômica da região de Puntland, localizada no Golfo de Aden, na costa norte da Somália. Nesse contexto, tem

\footnotetext{
${ }^{5}$ Conferência Internacional sobre Pirataria e Crimes no Mar, Kuala Lumpur, Malásia - maio de 2009.
} 
destaque a cidade portuária de Eyl, o mais tradicional destino dos navios capturados em alto mar. O município já possui inclusive empresas especializadas em serviço de alimentação de reféns. Ademais, é destacável a quantidade de atos piratas relacionados à região central de Arardhere. Para se dimensionar de forma exata a grandiosidade das atividades piratas somalis é válido observar que, apenas no ano de 2008, sessenta navios foram seqüestrados, resultando num total que já se acredita superar os US\$ trinta milhões em recompensas.

Sem a opção da pesca, devido à presença dos grandes pesqueiros internacionais, muitos dos pescadores somalis se voltaram para outras atividades, como o tráfico de armas e a pirataria. Os piratas somalis são em sua maioria provenientes da cidade de Harardhere, na Somália central e de Puntland. Ambas as regiões dependem fortemente da indústria pesqueira e, portanto, são palco da ameaça pirata. No contexto de fome e desespero, a pirataria é a melhor saída para os moradores locais. Ademais, os pescadores também são freqüentemente confundidos com piratas, por suas embarcações serem similares, e assim, são atacados sem nada ter feito. Em Puntland, os líderes destas atividades são imbuídos por uma aura de heroísmo nacional. Atribuindo à pesca a origem da pirataria somali, os homens envolvidos nos ataques a embarcações proclamam-se não como piratas, mas como guardas costeiros que defendem os interesses de seu país contra pesca ilegal e despejo de lixo tóxico na ausência de um governo funcional que impeça isto, pois afastariam os navios pesqueiros estrangeiros ilegais da costa. Entretanto, pode-se afirmar que estão neste tipo de atividade pelos enormes lucros que conseguem os piratas. Eles também contam com apoio popular, pois quando retornam com a renda obtida por meio dos resgates, distribuem parte dos ganhos na comunidade, angariando assim seu apoio.

\subsection{Perfil dos piratas modernos da Somália}

É preciso salientar que os piratas não são somente antigos pescadores. Grande parte dos piratas são grupos não estatais armados provenientes de toda a costa somali e mesmo do interior do país. Têm-se desenvolvido grupos altamente profissionalizados e organizados; a pirataria não se trata apenas de uma atividade oportunista, mas sim de um oportunismo sistematicamente estruturado, sendo os ganhos obtidos reinvestindo em equipamentos modernos que conferem maior poder 
aos piratas. Neste cenário, forças oficiais estão cada vez mais distantes de combater a economia paralela.

Ao final de 2008, observou-se na costa da Somália a formação de uma verdadeira indústria da pirataria. Os piratas somalis já atuam na posse de armamento pesado e barcos velozes, além de possuírem sofisticados planos de ação. Inicialmente, grupos de cerca de dez homens interceptam embarcações maiores e, com a ajuda de cerca de cinqüenta outros piratas que se aproximam em seguida, conseguem render a tripulação dos navios atacados. A lucratividade das incursões piratas advém das altas recompensas recebidas em troca das pessoas mantidas como reféns e dos barcos retidos; a média é de US\$ 2 milhões por embarcação seqüestrada. Pela necessidade de se obter dinheiro de resgates, os piratas, em geral, não praticam qualquer tipo de violência com relação aos aprisionados.

A forma de abordagem dos piratas modernos evoluiu, tendo em vista o incremento da especialização neste tipo de crime e o reinvestimento dos lucros na compra de armamentos mais portáteis e letais. A tabela 1 mostra a evolução do uso de armas de fogo na abordagem dos piratas de 2003 a 2008 - ênfase para o uso de armas de fogo. A tabela 2 mostra a evolução do tipo de violência praticada pelos piratas de 2003 a 2008 - ênfase para os casos de sequestro.

\begin{tabular}{|r|c|c|c|c|c|c||}
\hline Category & $\mathbf{2 0 0 3}$ & $\mathbf{2 0 0 4}$ & $\mathbf{2 0 0 5}$ & $\mathbf{2 0 0 6}$ & $\mathbf{2 0 0 7}$ & $\mathbf{2 0 0 8}$ \\
\hline Attempted & 93 & 77 & 52 & 56 & 62 & 47 \\
\hline Fired upon & 20 & 13 & 19 & 7 & 14 & 46 \\
\hline Hijack & 19 & 11 & 23 & 14 & 18 & 49 \\
\hline Missing & 2 & - & - & - & - & - \\
\hline Boarded & 311 & 228 & 182 & 162 & 169 & 151 \\
\hline Total & $\mathbf{4 4 5}$ & $\mathbf{3 2 9}$ & $\mathbf{2 7 6}$ & $\mathbf{2 3 9}$ & $\mathbf{2 6 3}$ & $\mathbf{2 9 3}$ \\
\hline
\end{tabular}

Tabela 1. Fonte: ICC-IBM - Piracy and Armed Robbery Against Ships Report-Annual Report 2008.

\begin{tabular}{|r|c|c|c|c|c|c||}
\hline Types of & $\mathbf{2 0 0 3}$ & $\mathbf{2 0 0 4}$ & $\mathbf{2 0 0 5}$ & $\mathbf{2 0 0 6}$ & $\mathbf{2 0 0 7}$ & $\mathbf{2 0 0 8}$ \\
\hline Violence & & & & & & \\
\hline Taken hostage & 359 & 148 & 440 & 188 & 292 & 889 \\
\hline Kidnap/Ransom & & 86 & 13 & 77 & 63 & 42 \\
\hline Crew threatened & 65 & 34 & 14 & 17 & 6 & 9 \\
\hline Crew assaulted & 40 & 12 & 6 & 2 & 29 & 7 \\
\hline Crew injured & 88 & 59 & 24 & 15 & 35 & 32 \\
\hline Crew killed & 21 & 32 & - & 15 & 5 & 11 \\
\hline Missing & 71 & 30 & 12 & 3 & 3 & 21 \\
\hline Total & $\mathbf{6 4 4}$ & $\mathbf{4 0 1}$ & $\mathbf{5 0 9}$ & $\mathbf{3 1 7}$ & $\mathbf{4 3 3}$ & $\mathbf{1 0 1 1}$ \\
\hline
\end{tabular}

Tabela 2. Fonte: ICC-IBM - Piracy and Armed Robbery Against Ships Report - Annual Report 2008. 


\section{A DEFINIÇÃO DE PIRATARIA}

Segundo Halberstam (1988), pirataria é o mais antigo e provavelmente o único crime pelo qual existe uma jurisdição universal reconhecida no direito internacional consuetudinário.

Existem, porém, diversas interpretações para este tipo de crime. Notadamente os interesses dos Estados, alegando aspectos ligadas às suas soberanias marítimas e o interesse dos EUA na defesa da supremacia e domínio dos mares, impedem que haja um entendimento jurídico uniforme.

\subsection{A definição da Convenção da Jamaica}

A definição de pirataria que ganhou notoriedade pública à luz da legislação internacional foi definida na Convenção das Nações Unidas sobre o Direito do Mar (CNUDM), realizada em Dezembro de 1982, na Jamaica. Não obstante, a primeira definição para o termo no ordenamento internacional, ocorreu na Convenção do Mar Alto, realizada em Genebra, em 1958. A conceituação era semelhante em ambos os Estatutos e era precária porque não abrangia os atos praticados no mar territorial, o que permitia que os piratas que atuassem nessa área ficassem numa situação de impunidade perante as leis internacionais.

O artigo 101 da CNUDM define a pirataria como:

"a) todo ato ilícito de violência ou de detenção ou todo ato de depredação cometidos, para fins privados, pela tripulação ou pelos passageiros de um navio ou de uma aeronave privados, e dirigidos contra:

i) um navio ou uma aeronave em alto mar ou pessoas ou bens a bordo dos mesmos;

ii) um navio ou uma aeronave, pessoas ou bens em lugar não submetido à jurisdição de algum Estado;

b) todo ato de participação voluntária na utilização de um navio ou de uma aeronave, quando aquele que o pratica tenha conhecimento de fatos que dêem a esse navio ou a essa aeronave o caráter de navio ou aeronave pirata;

c) toda a ação que tenha por fim incitar ou ajudar intencionalmente a cometer um dos atos enunciados nas alíneas a) ou b)."

\footnotetext{
${ }^{6}$ Documento disponível em http://www.un.org/Depts/los/convention_agreements/convention_overview_ convention. htm >
} 
Segundo esta definição, a pirataria deve seguir três critérios: objeto, lugar e propósito. Primeiro, o objeto do ato deve ser um navio, aeronave, a tripulação os passageiros desses veículos. Em segundo lugar, deve acontecer "em um lugar fora da jurisdição de qualquer Estado". Assim, todos os atos cometidos em águas internas, mar territorial e zona econômica exclusiva $(\mathrm{ZEE})^{7}$ não seriam considerados pirataria.

Os dois primeiros critérios são claros e objetivos, porém o terceiro é subjetivo por sua própria natureza. Quando se fala em propósito de um ato de pirataria depara-se com tema sujeito a diferentes interpretações. Por exemplo, não está claro se o animus furandi, a intenção de roubar é um elemento necessário. Se, por exemplo, a atuação de insurgentes tentando derrubar seu governo deva ser excluída do enquadramento na definição.

Segundo Halberstam (1988), os Tribunais dos Estados Unidos da América e do Reino Unido assumiram a posição de que qualquer ato ilícito de violência cometidos no alto mar é pirataria e que o roubo em si não é um elemento essencial.

\subsection{A definição da Organização Marítima Internacional}

Apesar dos problemas que cercam a definição aceita de pirataria da CNUDM, a Organização Marítima Internacional (OMI $)^{8}$ utiliza, para efeitos práticos, uma definição ampla que inclui, além dos atos de pirataria englobados pelo artigo 101, os assaltos à mão armada, ataques em águas interiores, mar territorial e ZEE para fins estatísticos.

Assalto à mão armada ${ }^{9}$ é definido pela OMI como "qualquer ato ilícito de violência ou com essa intenção, qualquer ato de depredação ou de ameaça, que não seja um ato de "pirataria", dirigido contra um navio, ou contra pessoas ou bens a bordo do mesmo, dentro da jurisdição do Estado sobre tais crimes". Dessa forma, a OMI procura especificar estes crimes para que sejam enquadrados nas estatísticas dos inúmeros ataques relatados nas últimas décadas, nos termos desta definição.

\footnotetext{
${ }^{7}$ A zona econômica exclusiva (ZEE) é a faixa que se estende até as 200 milhas marítimas das linhas de base a partir das quais se mede a largura do mar territorial.

${ }^{8}$ A Organização Marítima Internacional (OMI) é uma agência especializada das Nações Unidas, localizada em Londres, Reino Unido, cujo objetivo principal é desenvolver e manter um quadro regulamentar global para o transporte marítimo, incluindo a segurança, as preocupações ambientais, questões jurídicas, cooperação técnica, a segurança e a eficiência do tráfego marítimo.

${ }^{9}$ Resolução A.922(22), anexo, parágrafo 2.2 do "Code of Practice for the Investigation of the Crimes of
} 


\subsection{A Convenção para a Repressão de Atos Ilícitos Contra a Segurança da Navegação Marítima}

Outro documento da ONU que é considerado um referencial para lidar com a pirataria é a Convenção para a Repressão de Atos Ilícitos Contra a Segurança da Navegação Marítima, conhecida como Convenção SUA ${ }^{10}$. Esta convenção foi o resultado de um incidente a bordo do Achille Lauro, um navio de cruzeiro de bandeira italiana sequestrado na sua travessia de Alexandria para Port Said, em Outubro de 1985. Os sequestradores eram membros da Frente de Libertação para a Palestina (FLP), uma facção da Organização de Libertação para a Palestina (OLP) e ameaçou matar os passageiros, caso Israel não libertasse 50 prisioneiros palestinos. $\mathrm{Na}$ tarde seguinte, depois de não terem suas reivindicações atendidas, eles atiraram contra Leon Klinghoffer, um judeu de nacionalidade norte-americana. Os EUA consideraram o ataque como pirataria, uma posição controversa, tendo em vista que, nas discussões sobre a Convenção SUA, os EUA mantiveram-se pouco empenhados em aceitar a definição da OMI.

Logo após o incidente, em novembro de 1986, a OMI criou uma comissão ad hoc para a elaboração de uma Convenção para a Repressão de Atos Ilícitos Contra a Segurança da Navegação Marítima.

O principal objetivo da Convenção SUA é garantir que ações adequadas sejam tomadas contra atos ilícitos contra os navios, que incluem a captura de navios pela força, os atos de violência contra pessoas a bordo dos navios, e a colocação de dispositivos a bordo de um navio com o propósito de destruí-lo ou danificá-lo. Apesar da obrigação dos governos de extraditar ou processar os alegados criminosos, isso está longe de ser uma tarefa fácil. A Convenção SUA tentou preencher o vazio legal ilustrado pelo incidente do Achille Lauro, fato que exemplificou quão problemático pode ser comprovar a motivação como sendo para "fins privados", parte da definição de pirataria.

A Convenção SUA depara-se com o problema de um crime que não está completamente definido na legislação internacional - o terrorismo marítimo - para

\footnotetext{
Piracy and Armed Robbery Against Ships".

${ }^{10}$ Convenção para o Combate aos Atos Ilegais Contra a Segurança da Navegação Marítima. Disponível em: < http://www.imo.org/Conventions/mainframe.asp?topic_id=259\&doc_id=686>. Para este estudo será utilizado o termo "Convenção SUA" por falta de correspondente em português.
} 
não falar em códigos de legislações nacionais. Segundo Goodwin (2006), por um lado, a pirataria é um crime que, juntamente com a escravidão e genocídio, foi tratado como jure gentium (jurisdição universal). Por outro lado, os crimes definidos pela Convenção SUA têm um tratamento controverso nas legislações nacionais, que geram dúvidas por ocasião da necessidade de perseguir piratas no mar.

\subsection{A polêmica sobre a definição de pirataria marítima}

Estender a definição de pirataria às águas territoriais é um assunto controverso. O primeiro obstáculo é a inviolabilidade da soberania nacional sobre os crimes cometidos no mar territorial e nas águas interiores (soberania absoluta) e na ZEE (relativa). A extensão de uma definição ampla, certamente não será aceita pelos países marítimos mais desenvolvidos, tendo em vista que isso permitiria a entrada de navios estrangeiros à procura de navios piratas em suas águas. Assim, a declaração da Grã-Bretanha é paradigmática:

"Seria inaceitável para o Reino Unido aceitar que a marinha de um Estado estrangeiro seja capaz de reivindicar a jurisdição sobre um ato de assalto à mão armada marítima nas águas territoriais do Reino Unido. Esta seria a $\underline{\text { conseqüência infeliz de envolver um ato de pirataria e um ato de assalto à mão }}$ armada marítima em uma definição (grifo nosso)." 11

É interessante notar que a imunidade dos navios em alto mar, especialmente navios de guerra e outros navios de Estado utilizado para fins nãocomerciais (art. 28 da Convenção da Jamaica) é, segundo Byers (2004), o fundamento legal para a mobilidade global da marinha de guerra dos EUA.

O depoimento do então consultor jurídico do Departamento de Estado dos EUA, William Howard Taft IV, é claro sobre os motivos da não adesão à Convenção da Jamaica:

"Juntar-se à Convenção vai de encontro aos interesses militares dos EUA. Como a potência marítima militar mundial, os Estados Unidos seriam os mais beneficiados com as regras de navegação estabelecidas [...]. Porém existe um risco de afetar a mobilidade e o acesso dos EUA que já era e sempre foi largamente aceito

\footnotetext{
${ }^{11}$ UNITED KINGDOM. HOUSE OF COMMONS- Transport committee- Piracy- Government Response to the Committee's Eighth Report of Session 2005-06. HC 1690. London: The Stationary Office Limited, 2006, p. 4.
} 
como direito legal [...]. É um risco assumir que é possível preservar indefinidamente a estabilidade da situação que os Estados Unidos atualmente desfrutam [...]. O costume internacional deve ser alterado pela prática dos Estados ao longo do tempo a fim de que não interfiram na estabilidade defendida pela Convenção." ${ }^{2}$

\section{5 "Formas de expressão" da pirataria}

Alguns analistas acreditam que a pirataria é apenas um problema antigo, que merece as mesmas respostas de antigamente. Recentemente, o Wall Street Journal $^{13}$ definiu a pirataria como "parte de um grande desafio para a civilização e a ordem internacional", descrevendo a ação recente da Marinha dos EUA contra os piratas que sequestraram um cidadão norte-americano a bordo de um navio (Maersk Alabama, de bandeira norte-americana). Já o National Review declarou que:

"Foi, em suma, uma lição sobre como as civilizações podem e devem lidar com os seus inimigos bárbaros. [...] Da mesma forma poderia se dizer sobre o resgate de quatro reféns pelos comandos da marinha francesa, três dias antes, ao largo da mesma costa somali. Dois piratas foram mortos pelos comandos da marinha francesa e três estão agora sob custódia da França. [...] cinco piratas vivenciaram uma nova face da justiça divina, ou seja parisiense, e uma potência civilizada demonstrou que pode vencer a pirataria com muito pouco esforço." ${ }^{\text {"14 }}$ (grifo nosso)

Outro problema é o mito de "tirar lições da história". Se as medidas consideradas necessárias no passado foram bem-sucedidas, elas podem ser replicadas com os mesmos resultados. Um exemplo dessa miopia simplista diante do problema pode ser vista na opinião de Max Boot, Analista de Estudos de Segurança Nacional no Council on Foreign Relations, que defende que "as probabilidades de que a pirataria somali venha desaparecer sem uma resposta robusta de nações marítimas são igualmente remotas. Ele defende que, mesmo que não haja interesse da comunidade internacional em estabilizar e manter a paz na Somália, ainda é possível reduzir a ameaça de piratas por meio de iniciativas militares e legais que não sejam a ocupação do território somali. Tudo o que é necessário é aplicar as lições da história.

\footnotetext{
${ }_{12}^{12}$ Documento disponível em < http://www.senate.gov/ armed_services/statemnt/2004/April/Taft.pdf >.

${ }^{13}$ The Wall Street Journal. (Eastern edition). New York, N.Y. 19 Nov. 2008. p. A.21.

${ }^{14}$ O'SULLIVAN. John. Piracy and civilization: a lesson for our time (military operations against piracy in modern times). National Review. New York, May 4, 2009, p. 42.
} 
$\underline{\text { Se as gerações anteriores conseguiram derrotar os corsários, os bucaneiros do Caribe, }}$ e os homens do Mar Vermelho, com certeza essa geração pode derrotar a ralé representada pelos ladrões do mar da Somália.." ${ }^{15}$ (grifo nosso)

Pirataria não é um problema a ser tratado exclusivamente com força, como alguns políticos e decisores políticos em Washington e Bruxelas poderiam pensar, mas em ações que tratem caso a caso. A falha neste raciocínio é que ele não leva em conta a variável dependente do problema: os seres humanos. Barbara Tuchman(1986) coloca a questão desta forma: "O problema é que no comportamento humano e na história, é impossível isolar ou repetir um determinado conjunto de circunstâncias.

A pirataria de hoje não é o mesmo problema que os nossos antepassados enfrentaram, mas um acontecimento único na história com diferentes causas e consequiências. Além disso, a pirataria não tem as mesmas causas ao redor do globo, embora chamada pelo mesmo nome. Logo que começamos a estudar a história da pirataria e como ela foi tratada no passado, percebemos que não é "o mesmo problema". Quentin Skinner (1969), tenta decompor os conceitos na tentativa de tirar lições das idéias na história (conceitos, como a pirataria, por exemplo), considerou que ao tirar lições da história para a solução dos nossos próprios problemas imediatos seria não só cometer uma falácia metodológica, mas algo como um erro moral. Mas, para aprender com o passado, a distinção entre o que é necessário e o que é meramente o produto das nossas próprias disposições contingentes, é aprender a chave para o auto-conhecimento.

No entanto, existem algumas semelhanças na pirataria de hoje que remontam ao século XVII: é amplamente praticada por meios privados, e implica uma espécie de indústria em torno dela, assim como o na época dos Killigrews. Embora semelhantes na forma, as causas são completamente diferentes, bem como suas interpretações. Pirataria não é o mesmo que terrorismo marítimo, ou seja, o uso do mar para perpetrar ataques terroristas. O Movimento para a Libertação de Aceh (GAM) na Indonésia e Frente Moro de Libertação Nacional (FMLN) nas Filipinas são exemplos de agentes terroristas que utilizam o mar para o seqüestro de navios ${ }^{16} \mathrm{e}$

\footnotetext{
${ }^{15}$ BOOT, Max. op. cit., p. 107

${ }^{16}$ O caso dos navios Suehiro Maru, próximo à Manila, em 1975 e Our Lady Mediatrix, em 2000 pelo MNLF.
} 
matar pessoas ${ }^{17}$, mas eles não o fazem por objetivos privados.

Por outro lado, os incidentes de pirataria na Somália tem sido vistos como um revival dos ataques da época das guerras bárbaras, apesar do contexto diferente. As águas da Somália, por exemplo, têm sido sujeitas à poluição por petróleo devido à limpeza de tanques de navios petroleiros antes de seguir para o Mar Vermelho e Ormuz. Segundo Middleton (2009), cerca de 16.000 navios por ano atravessam o Golfo de Aden, que transporta petróleo do Oriente Médio e mercadorias da Ásia para a Europa e América do Norte. Assim, os ataques conduzidos pelos piratas somalis contra navios que fazem esse transporte têm uma motivação diferente dos ataques das Guerras Bárbaras do século XIX.

A tipologia dos atos de pirataria seria útil para analisar o fenômeno, embora não seja o objetivo deste trabalho. Anderson (2001) oferece uma classificação satisfatória do que ele denomina como "forma de expressão" de pirataria. Segundo este, a pirataria seria parasitária, que se alimenta do intenso e valioso comércio marítimo; episódica, pelo rompimento ou a distorção dos padrões comerciais normais; e intrínsecas, quando pirataria e os movimentos predatórios são partes da estrutura fiscal e comercial da sociedade. Os ataques na costa da Somália podem ser considerados parasitários e intrínsecos, especialmente devido à dissolução do governo da Somália e de sua marinha, após 1991.

\footnotetext{
${ }^{17} \mathrm{O}$ caso do Superferry 14, em 2004, quando morreram 116 pessoas - MURPHY, Martin. Contemporary piracy and maritime terrorism. The threat to international security. Adelphi paper n. 388. London: The International Institute for Strategic Studies. 2007, cap 2..
} 


\section{GLOBALIZAÇÃO E A PIRATARIA}

Desde o século XIX houve um aumento constante no comércio mundial. As transações comerciais que levavam meses agora são concluídas em questão de segundos. Apesar do aumento do volume de mercadorias transportadas por via aérea, a maioria é transportada por via marítima e estão sujeitas a atrasos, acidentes, problemas de descarga, impostos, terminais lotados e roubo. O comércio por mar tornou-se vital para o crescimento e sustentação econômica de muitos Estados.

\subsection{A importância estratégica do Golfo de Aden}

O Golfo de Aden é uma passagem estratégica do comércio marítimo internacional e é também considerada a região mundialmente mais propensa a ataques piratas. Cerca de $70 \%$ da pirataria marítima do mundo concentra-se nessa região. Cerca de $12 \%$ do comércio marítimo internacional e $8 \%$ do transporte de petróleo e derivados transportados pelo mar também utilizam a rota das águas do Chifre da África para navegação.

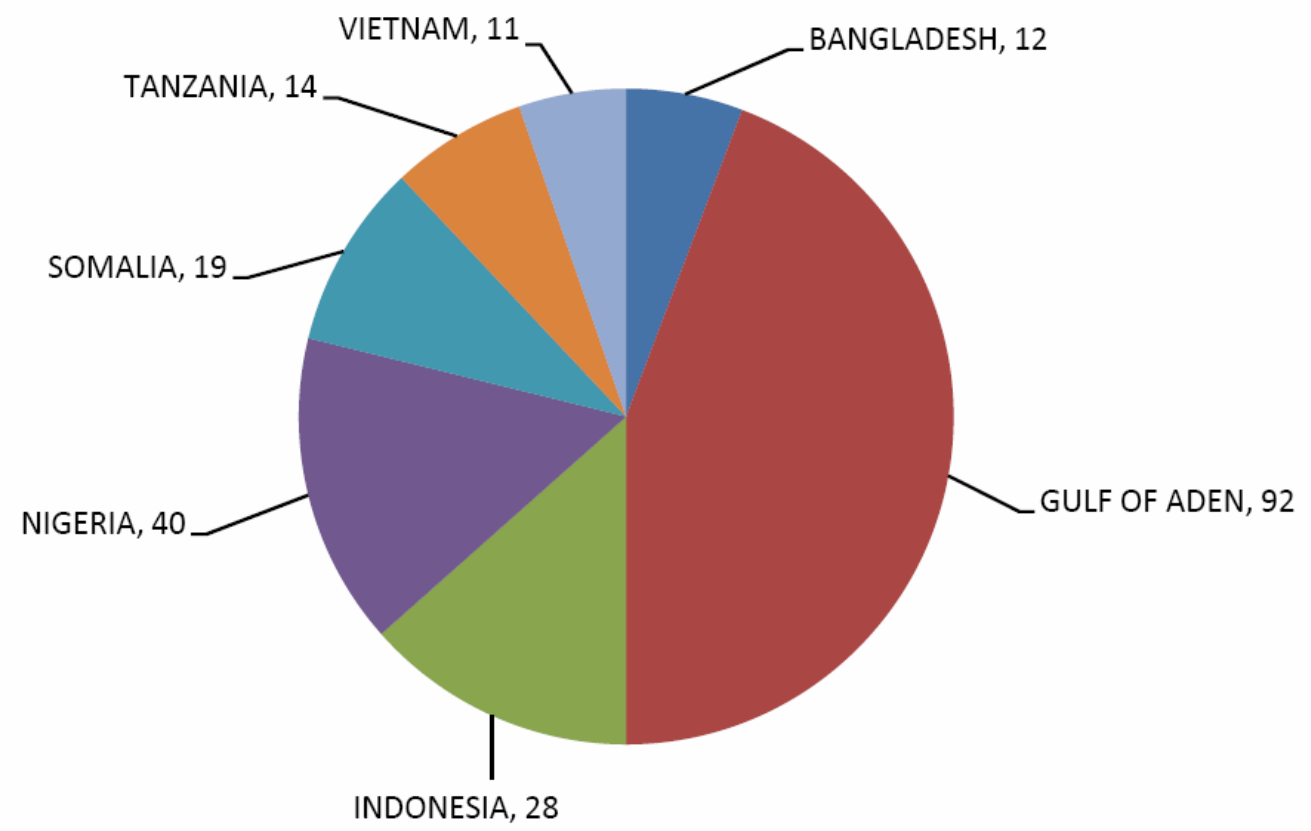

Figura 2 - A distribuição da pirataria no mundo em 2008. Fonte: ICC/IMB - Piracy and Armed Robbery Against Ships Annual Report

\subsection{O impacto da pirataria no comércio marítimo internacional}

A ocorrência da pirataria na Somália proporciona uma série de prejuízos 
econômicos, incluindo pagamentos de resgate, danos aos navios e cargas, os atrasos na entrega de cargas, aumento das taxas de seguro marítimo, os custos das medidas para proteger os navios mercantes contra os ataques, e os custos para usar as forças navais de operações anti-pirataria. Os custos econômicos totais da pirataria, apesar de significativo em termos absolutos, são apenas uma fração muito pequena do valor total do comércio marítimo mundial. Em depoimento em fevereiro de 2009, perante o Comitê de Transporte e Infra-estrutura, Subcomissão da Guarda Costeira e dos Transportes Marítimos dos EUA, Peter Chalk, analista sênior de política na Rand Corporation, afirmou que o custo global anual de pirataria para a indústria marítima é estimado entre US \$ 1 bilhão e US \$ 16 bilhões. Alguns desses custos são, em última análise, pagos pelo consumidor. ${ }^{18}$

Em maio de 2008, as seguradoras no Lloyds of London classificou o Golfo de Aden como "risco de zona de guerra" e o prêmio ficou sujeito a um seguro especial. Seguradoras com sede em Londres aumentaram as taxas para os navios de fazer a viagem pelo Golfo de Aden e pelo Canal de Suez. ${ }^{19}$

As empresas de navegação sediadas em Londres, quando sujeitas a um ataque pirata nos seus navios, geralmente se dispõem a pagar o resgate solicitado quando as quantias pedidas são consideradas baixas (variando de US\$500 mil a US\$2 milhões), comparado com o valor dos navios e das cargas ${ }^{20}$. Esses pagamentos são reembolsados por apólices de seguro de casco emitidas em Londres. No entanto, quando o resgate exigido excede o valor da carga, as empresas geralmente não pagam o resgate.

Operadores de navios (e seus governos) podem julgar que os custos do pagamento de resgates ocasionais são inferiores aos custos de tomar medidas para evitar eventuais sequestros, tais como mudança de itinerário ou de prover defesa armada dos seus navios mercantes. Alguns afirmam que o pagamento de resgates chegou a um equilíbrio e que mantém o nível de violência associados à pirataria na costa da Somália relativamente baixo e, quando os pagamentos de resgate individual são significativos, a pequena percentagem de navios que realmente são atacados e

\footnotetext{
${ }^{18}$ CRS Report R40081, Ocean Piracy and Its Impact on Insurance, Rawle O. King, Washington, DC, 2009.

${ }^{19}$ Piracy Threat Hikes Insurance Premiums: Insurers to Raise Rates in High-Risk Areas After Piracy Heists Off Somali Coast, Nov. 2008, disponível em <http://www.msnbc.msn.com/id/278262>

${ }^{20}$ Robert F. Worth, "Pirates Seize Saudi Tanker off Kenya: Ship Called the Largest Ever Hijacked,” New York

Times, 18 Nov. 2008, p. A. 6.
} 
capturados com sucesso reduz o risco global aos olhos de algumas entidades comerciais. Nesse sentido, os operadores de navios (e seus governos) lamentam os custos dos resgates, porém aceitam esse valor como sendo tolerável para o fechamento do negócio, mesmo que isso incentive mais a pirataria.

\subsection{0 "ciclo virtuoso marítimo"}

Geoffrey Till ${ }^{21}$, professor de Estudos Marítimos no Departamento de Estudos de Defesa no King's College da Universidade de Londres, procura avançar no conceito de "boa ordem" no mar. Segundo ele, o mar tem quatro atributos históricos que são essenciais para o desenvolvimento humano: o mar como um recurso, como meio de transporte, informação e domínio. Estes são interligados e interdependentes, de modo que a pirataria atua sobre o comércio marítimo de forma parasitária, para citar a tipologia de Anderson (2001). Geoffrey Till (2004) estabelece o conceito de "ciclo virtuoso marítimo", que seria representado conforme a figura a seguir:
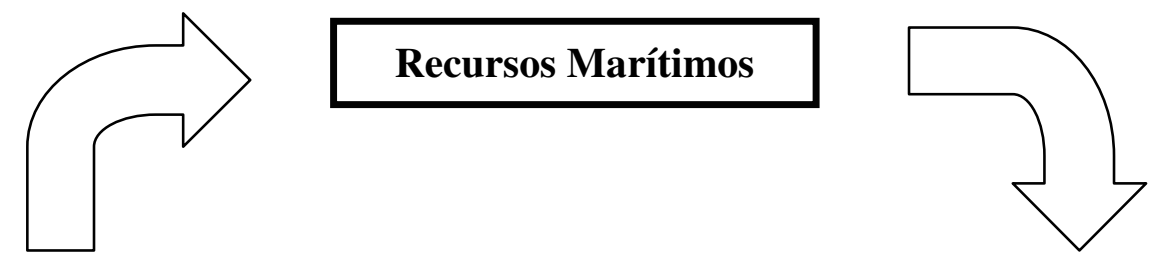

\section{Comércio Marítimo}

\section{Força Naval}

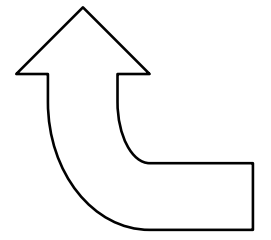

\section{Supremacia Marítima}

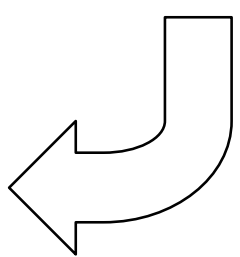

Figura 3 - Ciclo Virtuoso Marítimo. Fonte: TILL, Geoffrey. Seapower (2004), p. 20.

Além disso, segundo o autor, esse ciclo virtuoso marítimo, se interrompido ou perturbado poderia provocar um choque profundo em toda a estrutura. Sir Walter Raleigh, considerou que "Aquele que comanda o mar, comanda o comércio, e sendo o Senhor do comércio do mundo é o Senhor da riqueza do

\footnotetext{
${ }^{21}$ Mais sobre o trabalho e do livro do professor Till encontra-se em http://www. kcl.ac.uk/ schools/sspp/ defence /staff/acad/gtill.
} 
mundo". Este velho ditado é tão próximo da realidade hoje quanto no século XVI, lembrando que a maior parte do movimento do comércio do mundo globalizado é feito pelo comércio marítimo. Assim sendo, a pirataria é um elemento fundamental na determinação do valor do seguro de um navio. Isso tem um impacto relevante nos aspectos de segurança marítima e nos interesses dos países afetados com a pirataria marítima em envidar esforços para combater esta interferência no seu comércio.

Pirataria não é mais um privilégio de rotas longínquas e vazias. Um dos locais preferidos para os ataques de piratas é o Estreito de Malaca, com uma média de 50.000 navios por ano, juntamente com Mar da China Meridional, do Golfo da Guiné, Indonésia e, mais recentemente, na Somália. Abaixo temos uma distribuição geográfica dos ataques, onde pode ser notada a concentração dessa atividade na África, especialmente no Golfo de Aden.

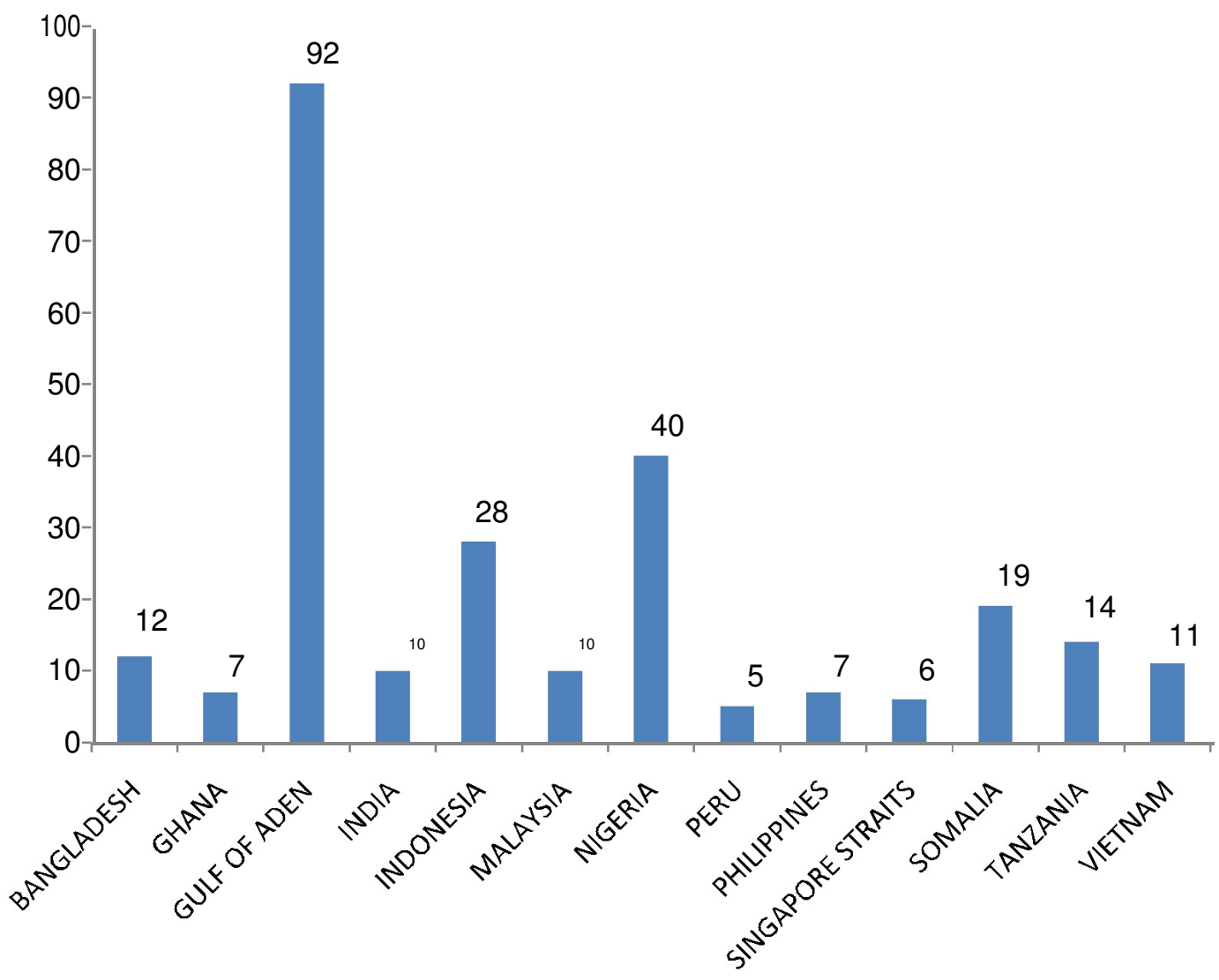

Tabela 1 : Países onde ocorreram 5 ou mais casos de ataques piratas e a comparação com o Golfo de Adem em 2008. Fonte: ICC-IBM - Piracy and Armed Robbery Against Ships Report-Annual Report 2008. 


\section{O COMBATE À PIRATARIA}

Existe ainda muita resistência política, questões de interoperabilidade e, especialmente, entraves encontrados nas legislações nacionais quando se trata de pirataria. Mesmo assim, a Organização Marítima Internacional está tentando assumir a liderança no combate à pirataria.

\subsection{Cooperação internacional}

Em novembro de 2004, dezesseis países assinaram o Acordo Regional de Cooperação sobre o Combate à Pirataria e aos Assaltos à Mão Armada Contra Navios na Ásia (RECAAP), que tem um gabinete de coordenação e um Centro de Compartilhamento de Informações (ISC, em inglês) para permitir a disponibilidade de informações entre os participantes.

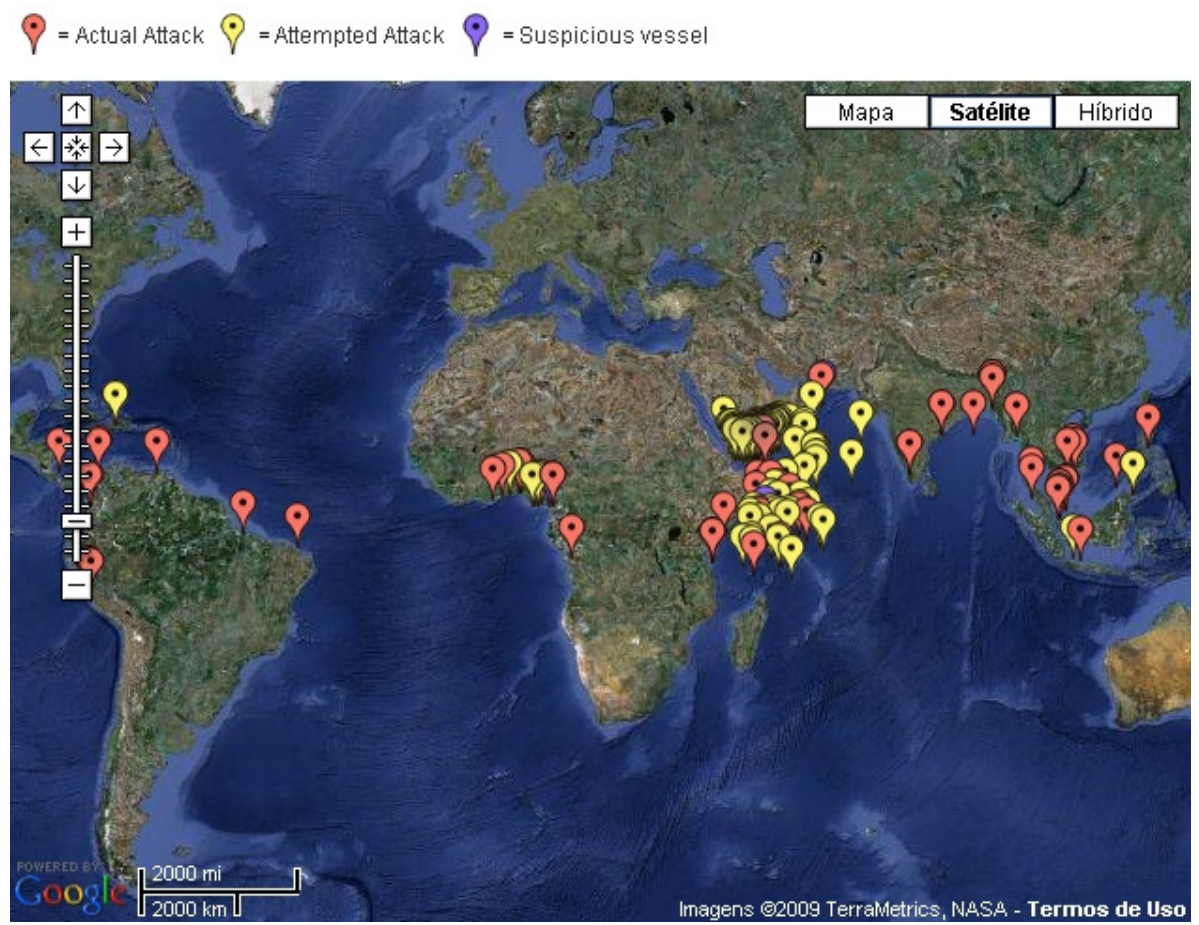

Figura 4 - Exemplo de quadro estatístico produzido pelo ISC.

Há também reuniões de coordenação regional. O primeiro deles ocorreu em Sana'a, no Iêmen, de abril de 2005 (para os países adjacentes ao Mar Vermelho e ao Golfo de Aden) e outro em Omã, em janeiro de 2006. Em setembro de 2005, uma reunião sobre o Estreito de Malaca e Cingapura realizado em Jacarta, na Indonésia.

O professor Till (2004, p. 337-338) afirma que "o mar deve ser pensado como um sistema global caracterizado por inúmeras interconexões em que uma 
perturbação em qualquer componente pode afetar todos os outros". Sendo assim, as principais ações da OMI são no sentido de assegurar maior conscientização marítima. A OMI contribui para essa "mentalidade marítima" 22 com, por exemplo, a manutenção de um registro estatístico sobre todos os ataques ou tentativas de ataques à navios relatados em todo o mundo. $\mathrm{O}$ relatório contém o nome do navio, localização, data, descrição do incidente, as conseqüências para a tripulação ou barco e as medidas tomadas pelas autoridades.

Outra questão importante é o trabalho do Comitê de Segurança Marítima da OMI no aconselhamento armadores, operadores e gestores de navios, companhias de navegação, comandantes e todas as outras partes envolvidas para prosseguir nos esforços para a plena aplicação das medidas preventivas contidas nas suas circulares. Algumas delas são especialmente importantes, como a recente "MSC.1/Circ.1333 Recomendações aos Governos para prevenção e repressão à pirataria e ao roubo à mão armada contra navios", que ainda sugere possíveis contra-medidas e a 'MSC.1/Circ.1334 - Guia para os armadores e operadores de navios, comandantes e tripulação na prevenção e repressão de atos de pirataria e assaltos à mão armada contra navios". 23

Embora tenham sido muito bem-vindas pela comunidade marítima, estas iniciativas não foram suficientes. Isto porque o comércio marítimo internacional está sujeito a uma diversidade de legislações nacionais e internacionais. Dessa forma, o caminho encontrado foi interdisciplinar que envolve todos os setores dos governos que possam ser úteis para esta questão.

A primeira ação do Conselho de Segurança da ONU concentrando-se exclusivamente sobre pirataria e assaltos à mão armada no mar foi por meio da Resolução 1816, de 2 de junho de 2008. Seguiu-se a Resolução 1838, de 7 de outubro de 2008, pedindo aos Estados para posicionarem seus navios e aviões militares "no alto mar ao largo da costa da Somália", assim como exortando-os para que "continuem a tomar medidas para proteger os comboios marítimos do Programa Mundial de Alimentos, vitais para levar assistência humanitária às populações

\footnotetext{
${ }^{22}$ Mentalidade Marítima de um povo é a compreensão da essencial dependência do mar para a sua sobrevivência histórica (VIDIGAL, A. A. F. et al. Amazônia Azul - o mar que nos pertence. Rio de Janeiro: Record, 2006, p. 21).

${ }^{23}$ Ambas aprovadas pelo Comitê de Segurança Marítima, em maio e junho de 2009. Disponível em <
} 
afetadas na Somália".

Além disso, instou os Estados-Membros a orientarem os seus navios, sobre "as medidas cautelares adequadas para se protegerem de um ataque ou das ações que devem ser tomadas quando atacados durante a navegação nas águas ao largo da costa da Somália ...”.

As ações tomadas para combate à pirataria tiveram várias origens, mas representam uma quebra de paradigma quando o assunto é a condução de ações multilaterais que envolvem segurança. Observa-se a ação de diversos Estados, Organizações Internacionais e associações de comércio internacional num movimento de combate a um problema de segurança sem a exclusiva liderança hegemônica dos Estados Unidos.

Observa-se, também, a ação de diversas organizações internacionais além da OMI, tais como a Câmara de Comércio Marítimo International (International Chamber of Shipping - ICS) e o Escritório Marítimo Internacional (International Maritime Bureau - IMB), que manifestaram preocupação com a escalada dos atos de pirataria, afirmando que para dar continuidade às suas ações seria imprescindível o emprego de escolta militar.

A OMI e outros órgãos como a Câmara de Comércio Internacional do Escritório Marítimo Internacional (IMB ICC) desenvolveram orientações detalhadas e recomendações para os governos e os navios comerciais que procuram prevenir, impedir e responder a ataques piratas. O IMB também criou um centro de informações que funciona 24 horas em Kuala Lumpur, na Malásia. Este centro pretende servir como porta de acesso principal para denúncias de pirataria e distribuição de informação contra a ameaça de pirataria para os navios comerciais. $\mathrm{O}$ IMB também trabalha com outros centros de informação regional para coletar e disseminar informação e divulgar alertas.

O primeiro sistema de identificação automática foi o AIS, sigla em inglês de Automatic Identification Sistem. O AIS foi criada pela Convenção Internacional para a Salvaguarda da Vida Humana no Mar (SOLAS-1974) ${ }^{24}$. É um sistema usado pelos navios e pelos diversos serviços de tráfego para identificação e localização dos navios. Ele fornece informações sobre o navio para outros navios e para as 
autoridades costeiras automaticamente, incluindo a troca de: identificação, posição, rumo e velocidade, com outros navios nas proximidades e os serviços de controle de tráfego. Esta informação pode ser exibida em uma tela nas estações de comando dos navios, ajudando os oficiais dos navios e permitindo que as autoridades marítimas acompanhem e monitorem os movimentos dos navios. Ele funciona através da integração de um sistema transceptor VHF padronizado com um sistema de navegação eletrônica, tais como LORAN-C (Long Version RAnge Navigation C) ou receptor do Sistema de Posicionamento Global( GPS, em inglês), e outros sensores de navegação a bordo do navio (giroscópio, indicador da velocidade angular, anemômetro e outros ). ${ }^{25}$

Em junho de 2008 foi enviada uma carta pelo Governo Federal de Transição da Somália ao presidente do Conselho de Segurança das Nações Unidas, solicitando ajuda da comunidade internacional em seus esforços para combater os atos de pirataria e assaltos armados cometidos contra navios na costa daquele país. A declaração que autorizou as nações a fazer acordos com o Governo Federal de Transição e a entrar em águas territoriais somalis para combater atividades piratas, foi aprovada por unanimidade.

Vários países e organizações internacionais estão ativamente engajados na região da crise. Em 2009 existiam três missões de marinhas no Golfo de Aden: o conjunto Task Force 151 (CFT - 151), liderada pelos EUA, a "Operação Atalanta", da Força Naval da União Europeia (UE NAVFOR) e operação "Ocean Shield", da OTAN. Além disso, em momentos diferentes, vários países enviaram navios de guerra em apoio das missões em andamento, dentre eles a China, Japão, Irã, Índia e Rússia. Ao todo, em 2009, cerca de 40 navios de guerra estavam engajados na luta contra a pirataria.

\subsection{Operação ATALANTA - União Europeia}

Em dezembro de 2008, a União Europeia criou o EU NAVFOR e denominou sua primeira operação de "ATALANTA', sua primeira operação naval na Política Europeia de Segurança e Defesa. As forças que participam na operação

\footnotetext{
${ }^{24}$ Capítulo 5, revisado em 2000.

${ }^{25}$ É obrigatória a utilização do AIS a bordo de todos os navios de arqueação bruta acima de 300 toneladas.
} 
ATALANTA receberam a tarefa de assegurar a proteção dos navios do Programa de Ajuda Humanitária e os navios mercantes e estão autorizados a "aplicar as medidas necessárias, incluindo o uso da força para deter, prevenir e intervir para combater atos de pirataria e assaltos à mão armada que possam ser cometidos nas áreas onde eles estão presentes." De acordo com a União Europeia, a força é composta por vinte navios e mais de 1.500 pessoas. Participam dessa operação a Grécia, França, Espanha, Alemanha e Itália. Está prevista a participação de outros Estados-Membros da UE. Também foi criado um centro de informações on line, conhecido como Centro de Segurança Marítima, Chifre da África (MSC-HOA) para o registro e acompanhamento voluntário. Este centro trabalha em coordenação com outros similares, como a Organização Marítima Reino Unido Comércio, em Dubai e da Marinha dos EUA, no Bahrein.

Os navios que voluntariamente aderem ao serviço podem utilizar o Corredor de Trânsito (FITRef), onde os navios da EU NAVFOR estão estrategicamente posicionados para impedir ataques de piratas e também para prestar apoio rápido no caso de navios mercantes atacados por piratas.

\subsection{Força Tarefa Combinada 151 - EUA e outros}

O Centro de Comando das Forças Navais (NAVCENT), da marinha dos EUA, fica localizada no Bahrein comanda as Forças Marítimas Combinadas que operam no Golfo Pérsico, Golfo de Omã, Golfo de Aden, Mar Vermelho, Mar Arábico e Oceano Índico. Em janeiro de 2009, foi estabelecido o comando "ForçaTarefa Combinada 151 (CTF-151)", com a única missão de realizar operações antipirataria no Golfo de Aden e nas águas da costa da Somália no Oceano Índico. Esse papel já era desempenhado pela CTF-150, que passou a se concentrar nas ações marítimas de contra-terrorismo e outras operações de segurança.

Em março de 2009, o CTF-151 era formado pelo pessoal de quase duas dezenas de navios dos Estados Unidos, Reino Unido, Canadá, Dinamarca, França, Alemanha, Grécia, Itália, Malásia, Holanda, Arábia Saudita, Espanha, Turquia e Iêmen. Ainda está prevista a participação do Bahrein, Jordânia, Japão, Singapura, República da Coreia, Suécia, Bélgica e Polônia. 


\subsection{Operação OCEAN SHIELD - OTAN}

Esta operação foi aprovada pelo Conselho do Atlântico Norte em 17 de agosto de 2009 e foi prorrogado até o final de 2012.

A Operação Ocean Shield foi a terceira operação da OTAN concentrada nas atividades contra a pirataria. Inicialmente a novidade dessa operação foi a introdução de um novo elemento à sua missão: ele ofereceu aos Estados regionais que solicitassem, assistência no desenvolvimento de sua própria capacidade de combater as atividades de pirataria.

Apesar da boa intenção, nenhuma ajuda para capacitação de defesa marítima de qualquer país foi concretizada. Infelizmente esse foi mais uma informação de marketing da combalida OTAN.

\subsection{Perspectivas do combate à pirataria}

O grande perigo de hoje é que a pirataria pode se transformar numa plataforma para o terrorismo, pois usando as técnicas dos piratas, por exemplo, os navios podem ser sequestrados e explodidos no meio de um estreito povoado ou um transatlântico capturado e passageiros de determinadas nacionalidades jogados ao mar.

No ano de 2008, a taxa de sucesso mundial da pirataria foi de $40 \%$. desde $1^{\circ}$ de janeiro até 20 de Abril de 2009, essa taxa de sucesso global subiu para 53\%. Somente no largo da costa da Somália, um aumento do número absoluto de ataques bastante alarmante, representando uma expansão sem precedentes das atividades no Oceano Índico, expandindo-se até 600 milhas ao largo da costa da Somália. ${ }^{26}$ (grifo nosso)

Apesar da crescente atuação dos organismos internacionais a fim de combater a atividade ilícita, em novembro de 2008, foi publicado trechos da entrevista com Noel Choong, Diretor do Centro de Observação da Pirataria do Escritório Marítimo Internacional, que tem sede em Kuala Lumpur: "A situação observada nas últimas semanas mostra um aumento anormal dos atos de violência e das capturas de navios, apesar do reforço da segurança na região. Na ausência de dissuasão, com riscos pequenos e a perspectiva de lucros elevados para os piratas, os

\footnotetext{
${ }^{26}$ Conferência Internacional sobre Pirataria e Crimes no Mar, Kuala Lumpur, Malásia - mai. 2009.
} 
ataques vão continuar. A situação já é incontrolável. Os Estados Unidos e a comunidade internacional devem fazer esta ameaça cessar" ${ }^{27}$

Tendo em vista os fatores históricos já mencionados e a falência do Estado somali, percebe-se que a pirataria é decorrente de problemas locais em terra, o que exige uma compreensão desse ambiente e, de ações conjuntas, tanto nacionais como da comunidade internacional mais próximas e coordenadas. ${ }^{28}$

Nesse sentido, um combate efetivo contra a pirataria só poderá ser alcançado se o estado de direito na Somália for restaurado e, mais fundamentalmente, se as causas subjacentes à pirataria forem eficazmente combatidas.

\footnotetext{
${ }^{27}$ Disponível em http://br.news.yahoo.com/s/afp/081119/mundo/som_lia_ar_bia__ndia.

${ }^{28}$ Idem.
} 


\section{QUESTÕES ENTRE O DIREITO INTERNACIONAL, MARÍTIMO E DIREITOS HUMANOS}

Sem a intenção de esgotar o assunto, esse estudo levantou alguns problemas sobre Direito Internacional que causam impacto nas medidas adotadas pelos governos, seja de forma isolada ou em conjunto quando se trata sobre os aspectos jurídicos dos crimes de pirataria.

Tendo em vista o caráter mundial da navegação marítima, foi vislumbrada a necessidade de acompanhamento automático dos navios. Um sistema que não dependesse da intervenção humana para informar, em tempo real, diversas sobre determinado navio. Essas informações são necessárias para um efetivo controle não só com o objetivo de controlar o tráfego de cargas, mas também de proporcionar um rastreamento que auxilie a prevenção e combate à qualquer tipo de crime que interfira nesse tráfego.

Assim como o AIS representou um avanço no controle do tráfego marítimo internacional, também apresentou uma vulnerabilidade muito séria qualquer navio equipado com AIS teria acesso a esses dados. John Grubb, do Departamento de Transportes do Reino Unido, destacou que "os movimentos do navio são muito públicos" e que "é fácil seguir navios, mesmo que você não tenha muita experiência no assunto, é possível obter as informações exatas sobre o que um determinado navio vai fazer. Dessa forma fica fácil qualquer pessoa com intenção criminosa ter acesso a essas informações ${ }^{29}$.

O Governo do Reino Unido orientou suas companhias de navegação a interromper temporariamente a radiodifusão do Sistema de Identificação Automática de sinais, quando em águas abertas (especialmente em águas afetadas pirataria conhecida), se julgam que a segurança do navio está comprometida. ${ }^{30}$

Além disso, existem pelo menos dezesseis empresas de radiodifusão de AIS que disponibilizam suas informações na internet, com dados sobre a carga, nome do navio e a sua posição, deixando os navios vulneráveis a ataques piratas. Por

\footnotetext{
${ }^{29}$ UNITED KINGDOM. HOUSE OF COMMONS. Transport committee- Piracy- eight report on session 2005-2006. HC 1026. London: The Stationary Office Limited, 2006, p. 24.

${ }^{30}$ Idem.
} 
exemplo, pode-se citar a MarineTraffic. $\operatorname{com}^{31}$ (portos gregos) e ShipAIS.com ${ }^{32}$, especializada em navios do Reino Unido.

O Comitê de Segurança da OMI, na sua $79^{\text {a }}$ sessão, em dezembro de 2004, decidiu que:

[...] os dados do AIS, disponíveis gratuitamente, sejam os dados gerados navio na internet ou em qualquer lugar transmitidos por navios poderiam ser prejudiciais para a segurança dos navios e das instalações portuárias e estava a prejudicando os esforços da Organização e dos Estados-Membros para reforçar a segurança da navegação e a segurança no sector dos transportes marítimos internacionais.

A Comissão considerou lamentável a divulgação dos dados do AIS na internet ou em outro lugar e instou os Estados-Membros, que sujeitassem os que fizessem essa divulgação às disposições das respectivas legislações nacionais, a fim de desencorajar aqueles que disponibilizam dados do AIS na internet ou em qualquer lugar.

Além disso, a Comissão condenou aqueles que irresponsavelmente publicam dados do AIS na internet ou fora dela, especialmente se a oferta partir de empresas de serviços de transportes marítimos e indústrias portuárias.

Esta recomendação, até o fim desse estudo, ainda não tinha produzido nenhum resultado prático $\mathrm{e}$ as informações sobre o tráfego marítimo ainda permanecem disponíveis e gratuitas na internet. Foi observado que as companhias de navegação da europa deixaram de disponibilizar as informações de forma gratuita, passando a cobrar pelo serviço que fica disponível mediante o preenchimento de uma ficha e o pagamento por cartão de crédito que pode ser feito por qualquer pessoa em qualquer parte do mundo. Dessa forma, o problema da segurança do tráfego marítimo continua bastante comprometida pelo fácil acesso às informações de posição, carga e rota dos navios em tempo real. ${ }^{33}$

\footnotetext{
${ }^{31}$ Disponível em <http:// www.marinetraffic.com/ais/>.

${ }^{32}$ Disponível em < http://www.shipais.com>.

${ }^{33}$ Disponível em < http://www.imo.org/Safety/mainframe.asp?topic_id=754 >
} 


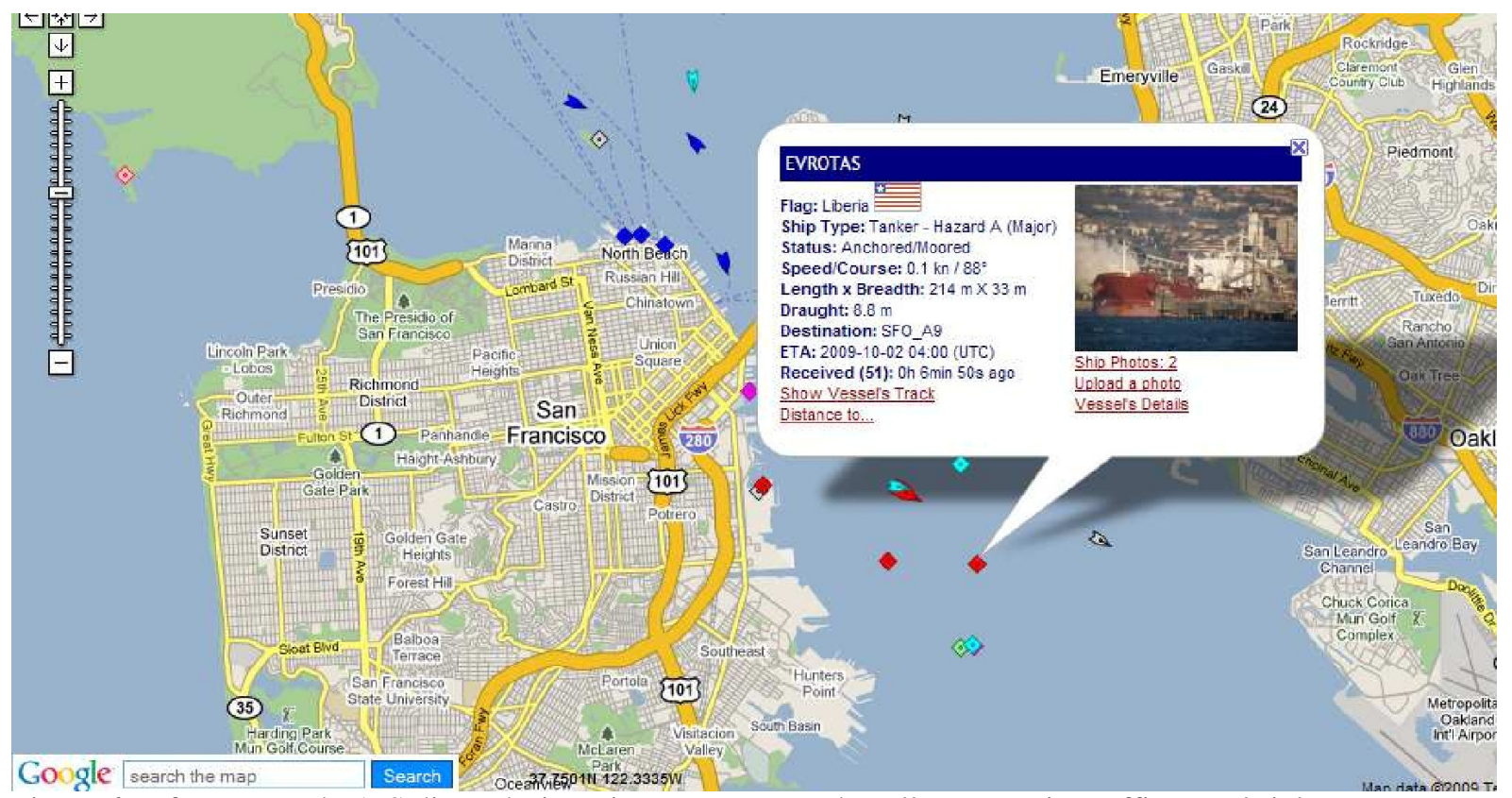

Figura 6: Informações do AIS disponíveis na internet. Fonte: <http://www.marinetraffic. com/ ais/>.

Outra questão importante envolve mais uma vez a definição de pirataria. Lembrando um ataque de pirataria em Hong Kong, em 1933, o Comitê Judicial do Conselho Privado ${ }^{34}$ foi perguntado se o roubo real foi um elemento essencial do crime de pirataria ou se uma tentativa frustrada foi suficiente para ser considerado como tal. Na verdade, dois barcos chineses atacaram outro navio chinês em alto mar. Um navio de guerra britânico capturou os agressores e os trouxe a julgamento em Hong Kong. Eles foram indiciados em Hong Kong para o crime de pirataria e considerados culpados pelo júri sujeitos a uma questão de direito: "Se um acusado pode ser condenado por pirataria em circunstâncias em que o roubo não ocorreu." Entretanto o Tribunal de Recurso de Hong Kong concluiu que o roubo era um ingrediente necessário do crime de pirataria e os acusados foram absolvidos. A questão da lei foi encaminhada ao Conselho Privado, que é o tribunal de recurso final para o Reino Unido. Segundo Johnson (1957), o Conselho absteve-se de oferecer uma definição de pirataria, embora tenha discutido várias definições, eventualmente afirmando que "o roubo em si não é um elemento essencial para o crime de pirataria". Este caso mostra que, embora a pirataria seja um crime na legislação internacional, na maioria dos casos, se não todos, eles são julgados por tribunais

\footnotetext{
${ }^{34}$ O Comitê Judicial do Conselho Privado é a corte de apelação final para os territórios ultramarinhos do RU.
} 
nacionais que podem ter uma visão diferente do crime, além de diversas penas diferentes, indo da advertência à pena de morte.

Finalmente, é importante considerar que, como mencionado anteriormente, a sentença de morte que pode ser infligida em um caso pode ter sérias repercussões por parte dos direitos humanos. A Marinha Real do Reino Unido tem sido especialmente utilizada na repressão à pirataria na Somália. Nesse sentido, segundo Woolf (2008), recentemente o ministério das relações exteriores do Reino Unido (FCO, em inglês) informou que os piratas capturados e enviados de volta para a Somália poderiam ter seus direitos humanos violados, pois, sob a lei islâmica, eles enfrentam a morte por decapitação por assassinato ou a mão cortada por furto".

Dessa forma, tendo os seus direitos humanos ameaçados, o acusado poderia, em teoria, pedir o asilo no Reino Unido. Um porta-voz do FCO declarou que: "Há questões sobre os direitos humanos e o que pode acontecer nestas circunstâncias. A principal questão é garantir que qualquer incidente seja resolvido pacificamente". O FCO foi duramente criticado por Julian Brazier MP, o porta-voz de navegação do partido Conservador, que disse: "Essas pessoas cometeram crimes horrendos. A solução não é fechar os olhos, mas entregá-los às autoridades locais. A convenção sobre os direitos humanos com toda a razão não compreende o alto mar. É uma decisão patética a que o nosso sistema jurídico chegou".

O medo das consequências de um maciço pedido de asilos provavelmente levou os Estados Unidos e a União Européia para emitir um entendimento com um terceiro, neste caso, no Quênia. Assim, em 2 de Junho de 2008, o Conselho de Segurança das Nações Unidas (CSNU) aprovou a Resolução 1816 (2008), convidando todos os Estados a cooperar na determinação da jurisdição e na investigação e ação penal das pessoas responsáveis por atos de pirataria e assaltos à mão armada ao largo da costa Somália. Em 10 de novembro de 2008, o Conselho aprovou a Ação Comum 2008/851/PESC relativa à operação militar da União Europeia para contribuir para a dissuasão, prevenção e repressão dos atos de pirataria e assaltos à mão armada ao largo da costa da Somália, denominada Operação "Atalanta".

Nesse sentido, a Ação Comum 2008/851/PESC prevê que as pessoas que tenham cometido ou que haja suspeita de terem cometido atos de pirataria ou assaltos à mão armada em águas territoriais da Somália, que estejam presos e detidos, tendo 
em vista a sua acusação, e os bens utilizados para efetuar tais atos, podem ser transferida para um Estado terceiro que pretenda exercer sua jurisdição sobre as referidas pessoas e bens, desde que as condições para a transferência tenham sido acordadas com esse Estado terceiro em consonância com o direito internacional aplicável, notadamente o direito internacional dos direitos humanos, a fim de garantir, principalmente, que ninguém deva ser submetido à pena de morte, tortura ou outro tratamento cruel, desumano ou degradante.

Portanto, com a anuência da Somália, o artigo 12 do Ato que instituiu a Operação ATALANTA, determina que os sujeitos ativos dos crimes de pirataria ou aqueles suspeitos de praticá-la, bem como os bens que tenham servidos para praticar o ato, sejam transferidos para as autoridades competentes do Estado-membro ou do Estado terceiro que participou da operação. Caso tal Estado não possa ou não deseje exercer sua jurisdição, que a pessoa ou bem capturado sejam transferidos para um Estado-Membro ou Estado terceiro que deseje exercê-la. A transferência da competência jurisdicional para outro país não pode ferir o direito internacional dos direitos humanos. Dessa forma, o artigo também prevê a impossibilidade do acusado ser transferido para um país onde haja aplicação de pena de morte, tortura ou outro tratamento cruel e desumano. ${ }^{35}$

Finalmente, em conformidade com o artigo 24 do Tratado da União Europeia, uma Troca de $\operatorname{Cartas}^{36}$ foi negociado entre a União Europeia e o Governo do Quênia sobre as condições e modalidades de transferência de pessoas suspeitas de terem cometido atos de pirataria e detidos pelas forças lideradas pela Força Naval da União Europeia (EUNAVFOR), assim como os bens apreendidos em posse de EUNAVFOR, da EUNAVFOR para o Quênia e o seu tratamento após a transferência.

É interessante notar que o entendimento da demanda respeita completamente as exigências das resoluções do Conselho de Segurança das Nações Unidas, a Convenção de 1982 das Nações Unidas sobre o Direito do Mar (CNUDM) (em especial os artigos 100-107) e Lei Internacional dos Direitos Humanos,

\footnotetext{
${ }^{35}$ Disponível em <http://eur-lex.europa.eu/ LexUriServ/ LexUriServ.do? uri=OJ:L:2008: 301: 0033: 0037: PT:PDF>

${ }^{36}$ EUROPEAN UNION. Jornal Oficial da União Europeia, 25/03/2008. Troca de cartas entre a União Europeia e o Governo do Quênia. Disponível em < http://eurlex.europa.eu/ Notice.do? val=491702: cs\&lang=en\&pos $=1 \&$ phwords $=$ piracy $\sim$ \& checktexte $=$ checkbox $>$
} 
incluindo o Pacto Internacional sobre Direitos Civis e Políticos de 1966 e a Convenção de 1984 contra a Tortura e Outros Tratamentos Cruéis, Desumanos ou Tratamentos Desumanos ou Degradantes. ${ }^{37}$

Nesse sentido, as transferências não poderiam ser realizadas sem um acordo. O Reino Unido, por exemplo, é clara a respeito da preocupação do governo: "Estas pessoas não podem ser transferidos para um terceiro Estado, incluindo a Somália, se as condições da transferência não foram acordadas com o terceiro Estado em conformidade com o direito internacional aplicável, notadamente a lei internacional dos direitos humanos, a fim de garantir que ninguém seja submetido a pena de morte, tortura ou outro tratamento cruel, desumano ou degradante." 38

É claro que o acordo com o Quênia foi feito por receio de que os piratas solicitassem asilo, como podemos ver a partir da resposta dada por Bob Ainsworth, o secretário britânico de Estado da Defesa, na Casa dos Comuns "Nós não temos intenção de fornecer um serviço de táxi para os requerentes de asilo em território britânico através da Royal Navy. Recebemos a cooperação dos países na área Quênia, em particular, como já disse - para levar essas pessoas à Justiça." ${ }^{39}$

Apesar do receio dos pedidos de asilo que os piratas poderiam reivindicar, o Secretário de Estado da Justiça afirmou (embora o FCO pareça não concordar) que mesmo que peçam, não é certo que isso aconteça. Em um debate na Câmara dos Comuns, ele considerou que os oficiais da Royal Navy poderiam ser impedidos de prender pessoas que cometem a pirataria no alto mar, porque tais alegados piratas teriam direito ao asilo. Na opinião do Secretário as pessoas podem pedir o que quiserem, mas não seria dado asilo, pois o Artigo $1^{\circ} \mathrm{F}$ da Convenção dos Refugiados de 1951 afirma que não se aplica a uma pessoa "em relação às quais existam sérias razões para acreditar que [...] ele cometeu um crime grave de direito comum fora do país de refúgio antes de sua admissão a este país como refugiado. Desta forma o Secretário afirma que "não há dúvida sobre o assunto - os piratas não podem ter um pedido de asilo atendido."

\footnotetext{
${ }^{37}$ EUROPEAN UNION. Op. cit.

${ }^{38}$ UNITED KINGDOM. HOUSE OF COMMONS LIBRARY. BUTCHER, Louise. Standard note SN/BT/3794. Shipping: Piracy. 31/03/2009.

${ }^{39}$ UNITED KINGDOM, HOUSE OF COMMONS DEBATES. 1 Jun. 2009. Volume 493, part 82, columns 5-6.

${ }^{40}$ UNITED KINGDOM, HOUSE OF COMMONS DEBATES. 4 2008. Volume 485, part 2, column 223.
} 
O Reino Unido não está sozinho no estabelecimento de acordos com o Quênia. Os Estados Unidos assinaram recentemente um memorando de entendimento, de forma similar com o Quênia. Stephen D. Mull, Secretária Assistente de Estado para Assuntos Políticos Militares, do Departamento de Estado dos EUA expressou a sua preocupação dizendo que "um grande problema é descobrir o que fazer com os piratas, uma vez apreendidos. E por isso temos trabalhado para garantir um acordo com o Quênia que terá todo o prazer em acolher os piratas que apreendemos e então processá-los. Temos também uma série de outras discussões em curso com outros Estados da região a fazer a mesma coisa”.

Em parte, é engraçado, mas também ilustra que, uma vez que os piratas estejam presos e sob custódia um Estado, pode haver leis nacionais que impeçam o seu regresso ao país de origem, mesmo se forem consideradas inocentes. Ao alegar que enfrentam perseguição ou péssimas condições de vida na Somália, os piratas encontram um forte argumento nas jurisdições nacionais de vários países. Dessa forma, segundo a Secretária Assistente, ficariam marginalizados no país de asilo e, em seguida, tornarem-se um problema para a nação (grifo nosso). ${ }^{41}$

Nesse sentido, o governo dos Estados Unidos entregou mais de 52 piratas ao Quênia que, até o fim desse estudo ainda aguardavam julgamento. ${ }^{42}$

Uma coisa a União Europeia conseguiu: com esperteza, ela encontrou uma solução africana para um problema internacional. Só que, ao colocar piratas diante de um tribunal no Quênia, a União Europeia infringe os mesmos direitos humanos cuja observância ela gosta de exigir dos países africanos. Pois é quase impossível que os piratas obtenham um processo justo no Quênia.

Segundo o repórter Daniel Pelz, do Deutsche Welle ${ }^{43}$, os tribunais quenianos estão cronicamente sobrecarregados e seus orçamentos são muito baixos. Alguns juízes precisam se ocupar com 50 casos por dia para conseguir superar sua carga de trabalho. Processos judiciais costumam durar vários anos. É frequente a perda de documentos ou o desaparecimento de provas.

Muitas vezes falta o dinheiro para computadores. A administração do setor judiciário é lerda e caótica. A UE perde sua credibilidade ao ignorar

\footnotetext{
${ }^{41}$ UNITED STATES HOUSE OF REPRESENTATIVES. One hundred eleventh congress. First Session. 30/04/2009. Serial no. 111-113.

42 Idem.
} 
deliberadamente que a Justiça do Quênia ainda não é independente. Há poucos dias a ministra da Justiça renunciou ao cargo porque o presidente, por conta própria, resolveu nomear novos juízes.

Em última instância, a União Europeia empurra para o Quênia um problema que ela ajudou a criar. Os piratas diante da costa somali são apenas uma consequência do colapso do Estado na Somália. Colapso, em tese, fomentado indiretamente ao longo dos anos pela Europa e pelos Estados Unidos.

${ }^{43}$ Disponível em <www1.folha.uol.com.br/folha/dw/ult1908u554594.shtml> 


\section{CONCLUSÃO}

Desde os tempos Eduardianos, a pirataria tem evoluído no seu método, embora mantendo a motivação da finalidade privada. A estrutura da família Killigrew pode ser vista quase duplicada na Somália com as marcas da modernidade, como telefones por satélite e metralhadoras. Não obstante, as causas são completamente diferentes, bem como as suas consequências.

Nas Guerras Bárbaras uma força-tarefa de navios de guerra tinha ordens para destruir os navios piratas e bombardear os países de acolhimento, mas este não é o caso hoje. Estudiosos e políticos defendendo uma estratégia semelhante de uso da força para lidar com a pirataria podem estar equivocados em sua análise, tendo em vista que a cooperação internacional nesse sentido, apesar dos inúmeros esforços, não têm logrado êxito no intenso uso da força. Talvez por que a pirataria de hoje seja diferente daquela praticada nos séculos XVIII e XIX.

A pretensão de estender a jurisdição universal sobre pirataria, considerada por alguns como inimigos da humanidade (hostis humani generis), é difícil de alcançar devido às diferenças entre as legislações nacionais e internacionais, conforme exemplificado pela orientação do FCO no Reino Unido para a Royal Navy.

Os piratas têm atacado navios em rotas mais movimentadas do comércio marítimo, especialmente no Estreito de Malaca e do Chifre da de África. Essas ações criminosas tendem a aumentar as taxas de seguro marítimo, bem como deixar o comércio marítimo sujeito a uma séria restrição.

As discussões jurídicas a respeito da pirataria são intermináveis e têm um único objetivo: manter os piratas capturados longe dos países ricos, fora até mesmo das prisões em seus territórios.

Apesar das diversas ações de cooperação internacional objetivando o combate à pirataria, pouco ou quase nada tem sido feito para o combate às causas do problema. Conforme mencionado, a falência do Estado somali e os altos lucros da indústri da pirataria marítima revelam que o problema está em terra, onde a Somália se destaca pelo caos no já conturbado contexto africano. 


\section{REFERÊNCIAS}

ANDERSON. John L. Piracy and World History. An economic perspective on maritime predation. In: PENNELL. C. R. Bandits at sea. New York: New York University Press, 2001, p. 82-106.

BOOT, Max. Pirates, then and now: how piracy was defeated in the past and can be again. Foreign Affairs, v. 88, n. 4 , Jul.-Aug. 2009, p. 94-107.

BULL, Hedley. A sociedade anárquica. Translation Sérgio Bath. São Paulo: Imprensa Oficial do Estado de São Paulo, 2002.

BYERS, Michael. Policing the High Seas: The Proliferation Security Initiative. The American Journal of International Law, v. 98, n. 3, Jul. 2004, p. 526-545.

CHENOWETH, Gene M. Melaka, "Piracy" and the Modern World System. Journal of Law and Religion, v. 13, n. 1, 1996 - 1999, p. 107-125.

CRAVEN, Frank. The Earl of Warwick, a Speculator in Piracy. The Hispanic American Historical Review, v. 10, n. 4, Nov. 1930, p. 457-479.

EUROPEAN UNION. Official Journal of the European Union. 25 Mar. 2009. L 79, p. 49- 59. Available at $<$ http://eurlex.europa.eu/ Notice.do?val=491702: cs\&lang $=$ en $\&$ pos $=1 \&$ phwords $=$ piracy $\sim$ checktexte $=$ ch eckbox $>$.

GOODWIN, Joshua Michael. Universal jurisdiction and the pirate: time for an old couple to part. Vanderbilt Journal of Transnational Law, v. 39, n. 3, May 2006, p. 973- 1011.

HALBERSTAM, Malvina. Terrorism on the High Seas: The Achille Lauro, Piracy and the IMO Convention on Maritime Safety. The American Journal of International Law, v. 82, n. 2, Apr. 1988, p. 269-310.

INTERNATIONAL MARITIME ORGANIZATION. MSC.4/Circ.133. Reports on acts of piracy and armed robbery against ships Annual report - 2008. London: Maritime Safety Committee. Disponível em http://www.imo.org/ includes/ blastData.asp/ doc_id=11376/133.pdf.

JOHNSON, D. H. N. Piracy in Modern International Law. Transactions of the Grotius Society, v. 43, Problems of Public and Private International Law, Transactions for the Year 1957, p. 63-85. Oxford University Press.

LICHE. La piraterie - Grande criminalité en mer. La Tribune. Paris: Collège Interarmées de Défense (CID), Apr., 2007. Disponível em: < http:// www. College .interarmees. defense.gouv.fr/spip.php?article687 >. Accessed on Jun. 15, 2008.

LUFT, Gal; KORIN, Anne. Terrorism Goes to Sea. Foreign Affairs, v. 83, n. 6, Nov.- Dec. 2004, p. 61. 
MATHEW, David. The Cornish and Welsh Pirates in the Reign of Elizabeth. The English Historical Review, v. 39, n. 155, Jul. 1924, p. 337-348.

MIDDLETON, Roger. Piracy in Somalia. Threatening global trade. Feeding local wars. Briefing paper. London: Chatham House. Disponível em < http://www.chathamhouse.org.uk/publications/papers/view/-/id/665/ >. Accessed on Jun. 01, 2009.

MURPHY, Martin. Contemporary piracy and maritime terrorism. The threat to international security. Adelphi paper n. 388. London: The International Institute for Strategic Studies. 2007

O'SULLIVAN. John. Piracy and civilization: a lesson for our time.(military operations against piracy in modern times). National Review. New York, May 4, 2009.

PISTONO, Stephen P. Henry IV and the English Privateers. The English Historical Review, v. 90, n. 355, Apr. 1975, p. 322-330.

PLANT, Glen. The Convention for the Suppression of Unlawful Acts against the Safety of Maritime Navigation. The International and Comparative Law Quarterly, v. 39, n. 1, Jan. 1990, p. 27- 56.

RIVKIN JR, David B.; CASEY, Lee A. Pirates Exploit Confusion about International Law. The Wall Street Journal. (Eastern edition). New York, N.Y.: 19 Nov. 2008. p. A.21.

SKINNER, Quentin. Meaning and Understanding in the History of ideas. History and Theory, v. 8, n. 1, 1969, p. 3-53.

SIDAK, J. Gregory. The quasi war cases - and their relevance to whether "letters of marque and reprisal" constrain presidential war powers. Harvard Journal of Law \& Public Policy, v. 28, n. 2, spring 2005, p. 465-499.

TILL, Geoffrey. Seapower. A guide for the twenty-first century. London: Frank Cass publishers, 2004.

TUCHMAN, Barbara. Is history a guide to the future? Practising history. New York: MacMillan. 1986, p. 249.

UNITED KINGDOM. HOUSE OF COMMONS DEBATES. 4 Dec. 2008. Volume 485, part 2, column 223. Disponível em < http://www.parliament.the-stationeryoffice.co.uk/pa/cm200809/cmhansrd/cm081204/debtext/81204-0017.htm >. Acessado em 4 Jan. 2009.

UNITED KINGDOM, HOUSE OF COMMONS DEBATES. 1 Jun. 2009. Volume 493, part 82, columns 5-6. Available at < http:// www.publications.parliament.uk /pa/cm200809/ cmhansrd/cm090601/debindx/90601-x.htm >. 
UNITED KINGDOM. HOUSE OF COMMONS LIBRARY. BUTCHER, Louise. Standard note SN/BT/3794. Shipping: Piracy. 31 Mar. 2009.

UNITED KINGDOM. HOUSE OF COMMONS- Transport committee- Piracyeighth report on session 2005-2006. HC 1026. London: The Stationary Office Limited, 2006.

UNITED KINGDOM. HOUSE OF COMMONS- Transport committee- PiracyGovernment Response to the Committee's Eighth Report of Session 2005-06. HC 1690. London: The Stationary Office Limited, 2006.

UNITED NATIONS. INTERNATIONAL MARITIME ORGANIZATION. Resolution A.922(22), annex, paragraph 2.2 of the Code of Practice for the Investigation of the Crimes of Piracy and Armed Robbery Against Ships.

UNITED NATIONS. INTERNATIONAL MARITIME ORGANIZATION. MSC.1/Circ.1333. PIRACY AND ARMED ROBBERY AGAINST SHIPS. Recommendations to Governments for preventing and suppressing piracy and armed robbery against ships. 26 Jun. 2009. Disponível em: < http://www.imo.org/includes/blastData.asp/doc_id=11564/1333.pdf >.

UNITED NATIONS. INTERNATIONAL MARITIME ORGANIZATION. MSC.1/Circ.1334. PIRACY AND ARMED ROBBERY AGAINST SHIPS. Guidance to shipowners and ship operators, shipmasters and crews on preventing and suppressing acts of piracy and armed robbery against ships. 23 Jun. 2009. Disponível em: < http:// www.imo.org/ includes/ blastData.asp/ doc_ id $=11565 / 1334$.pdf $>$.

UNITED STATES HOUSE OF REPRESENTATIVES. International efforts to combat maritime piracy. Hearing before the subcommittee on international organizations, human rights and oversight of the Committee on Foreign Affairs. House of Representatives. One hundred eleventh congress. First Session. Apr. 30, 2009. Serial no. 111-113. Available at: < http://www.foreignaffairs.house.gov/ >. Accessed on Jun. 12, 2009.

UNITED STATES SENATE. Testimony on the accession to the 1982 Law of the Sea Convention and ratification of the 1994 agreement amending part XI of the Law of the Sea Convention before Senate Armed Services Committee on April 8, 2004. Senate Treaty Document 103-39. Senate Executive Report 108-10. Available at: < http://www.senate.gov/ armed_services/statemnt/2004/April/Taft.pdf >. Accessed on Apr. 20, 2008, p. 3; 8 .

ZAGO, Evandro F., MINILLO, Xaman K. P. Consequências da falência de um Estado: pirataria nas águas da Somália. UNB, Brasília, DF. Nov. 2008. Disponível em <http://meridiano47.info/2008/11/23/consequencias-da-falencia-de-um-estadopirataria-nas-aguas-da-somalia-por-evandro-farid-zago-xaman-korai-pinheirominillo/> 